\title{
Review \\ A Review on LDH-Smart Functionalization of Anodic Films of Mg Alloys
}

\author{
Mosab Kaseem ${ }^{1, *}$, Karna Ramachandraiah ${ }^{2}$, Shakhawat Hossain ${ }^{3}$ and Burak Dikici ${ }^{4}$ (D) \\ 1 Department of Nanotechnology and Advanced Materials Engineering, Sejong University, Seoul 05006, Korea \\ 2 Department of Food Science and Biotechnology, College of Life Science, Sejong University, \\ Seoul 05006, Korea; karna@sejong.ac.kr \\ 3 Department of Industrial and Production Engineering, Jashore University of Science and Technology, \\ Jashore 7408, Bangladesh; shakhawat.ipe@just.edu.bd \\ 4 Department of Metallurgical and Materials Engineering, Ataturk University, Erzurum 25240, Turkey; \\ burakdikici@atauni.edu.tr \\ * Correspondence: mosabkaseem@sejong.ac.kr
}

check for

updates

Citation: Kaseem, M.

Ramachandraiah, K.; Hossain, S.; Dikici, B. A Review on LDH-Smart Functionalization of Anodic Films of Mg Alloys. Nanomaterials 2021, 11, 536. https://doi.org/10.3390/ nano11020536

Received: 24 January 2021

Accepted: 17 February 2021

Published: 19 February 2021

Publisher's Note: MDPI stays neutral with regard to jurisdictional claims in published maps and institutional affiliations.

Copyright: (c) 2021 by the authors. Licensee MDPI, Basel, Switzerland. This article is an open access article distributed under the terms and conditions of the Creative Commons Attribution (CC BY) license (https:/ / creativecommons.org/licenses/by/ $4.0 /)$.

\begin{abstract}
This review presents an overview of the recent developments in the synthesis of layered double hydroxide (LDH) on the anodized films of $\mathrm{Mg}$ alloys prepared by either conventional anodizing or plasma electrolytic oxidation (PEO) and the applications of the formed composite ceramics as smart chloride traps in corrosive environments. In this work, the main fabrication approaches including co-precipitation, in situ hydrothermal, and an anion exchange reaction are outlined. The unique structure of LDH nanocontainers enables them to intercalate several corrosion inhibitors and release them when required under the action of corrosion-relevant triggers. The influences of different variables, such as type of cations, the concentration of salts, $\mathrm{pH}$, and temperature, immersion time during the formation of $\mathrm{LDH}$ /anodic film composites, on the electrochemical response are also highlighted. The correlation between the dissolution rate of PEO coating and the growth rate of the LDH film was discussed. The challenges and future development strategies of LDH/anodic films are also highlighted in terms of industrial applications of these materials.
\end{abstract}

Keywords: Mg alloys; anodic film; layered double hydroxide layer; smart functionalization; corrosion

\section{Introduction}

Material degradation, specifically corrosion, is a serious issue limiting the use of active metals like magnesium in advanced applications [1]. $\mathrm{Mg}$ and its alloys have high specific strengths by which they can replace heavy metals in different technological sectors [1]. Therefore, it is highly important to improve the electrochemical stability of these materials in corrosive environments to extend their applications. To date, several methods, such as sol-gel coating, chemical vapor deposition, anodizing, and plasma electrolytic oxidation (PEO) have been utilized to enhance the protective properties of light metals and their alloys [2-10]. Among them, the anodizing method discovered in 1923 has been used extensively to form thin protective anodic films [7]. As an updated version of anodizing, $\mathrm{PEO}$ is an emerging method because of its unique plasma-in-water system. Typically, PEO transforms metal surfaces into a robust layer of their corresponding oxides using numerous micro-sized plasma discharges, which are generated as the result of electrical breakdown events at high overvoltages [7]. These micro-sized plasma discharges induce a high-temperature environment $(\mathrm{T}>\sim 3500 \mathrm{~K})$ that is above the melting point of most metals and oxides [11], leading to a dynamic surface topography comprising micropores due to local and repetitive melting-solidification cycles. However, due to the thin layer and/or the porous structure of the anodic films produced via anodizing and PEO, the corrosive species would reach the metallic substrate, leading to its corrosion in extreme environments [7]. An additional treatment, therefore, must be applied to the anodic 
films towards achieving higher electrochemical stability for large-scale applications [7,12] Several research groups have used several approaches, such as the typical sealing by boiling water [13], post-treatment using polymers or organic compounds [7,14], post-treatment by sol-gel coatings [15] in order to enhance the stability of anodic films of Mg alloys. However, the boiling water approach would not be desirable on account of the slight improvements in the protective properties as well as the high energy consumption associated with this method [7]. Moreover, the application of polymers and organic compounds to seal the anodic films would be limited due to the susceptibly of these materials to degradation at elevated temperatures. Also, the use of sol-gel coatings led to the formation of many cracks as a result of mismatching between the metal oxides incorporated by the sol-gel approach and $\mathrm{MgO}$ which is known to be the main component of the anodic films produced on $\mathrm{Mg}$ alloy via anodizing and PEO [7].

In addition to the approaches described above, layered double hydroxides (LDHs) can provide another approach to improve the protective properties by increasing the barrier properties [16-21]. LDHs are lamellar crystals with positively charged brucitelike host layers with interlayer regions containing charge-compensating anions and solvation molecules $[22,23]$. The typical formula of these materials can be described as $\left[\mathrm{M}_{1-\mathrm{x}}{ }^{2+} \mathrm{M}_{\mathrm{x}}{ }^{3+}(\mathrm{OH})_{2}\right]\left(\mathrm{A}^{\mathrm{n}-}\right)_{\mathrm{x}} / \mathrm{n} \cdot \mathrm{mH}_{2} \mathrm{O}$, where $\mathrm{M}^{2+}$ and $\mathrm{M}^{3+}$ are the divalent and trivalent cations, respectively, while, $\mathrm{A}^{\mathrm{n}-}$ is the interlayer anion (Figure 1) [18]. Such inorganic nano-containers have been widely proposed to improve the corrosion resistance of $\mathrm{Mg}$ and its alloys on account of their merits, such as small size, high loading capacity, and simple modification [24-35]. Moreover, such materials have an excellent anion-exchange capability by the simultaneous release of interlayer anions and the adsorption of aggressive species from the corrosive environment. Therefore, LDH-based protective films can be considered as smart coatings, meaning that they can control the liberation of corrosion inhibitors and improve the long-term corrosion performance.
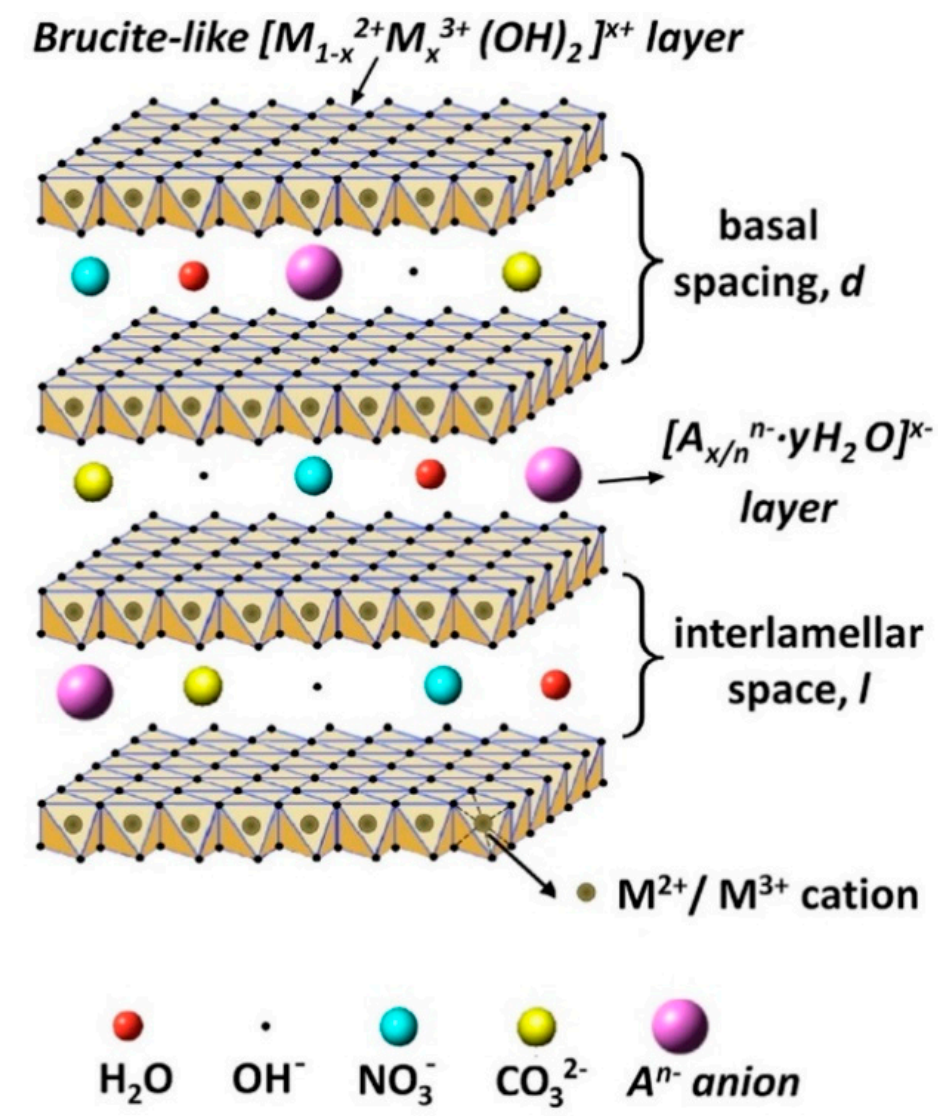

Figure 1. The general crystal structure of layered double hydroxide (LDH) film. Reprinted with permission from ref. [18]. Elsevier 2019. 
Anodization of the $\mathrm{Mg}$ alloys surface results in the formation of magnesium oxide $(\mathrm{MgO})$ that acts as the major source of $\mathrm{Mg}^{2+}$ for the dense growth of LDHs, while LDH precursors are found to seal the anodic surface and can provide better active and passive corrosion protection with long-term stability. Moreover, the LDH films made on the anodic coating of $\mathrm{Mg}$ alloys can also increase the thickness of the protective film and, therefore, such factors could effectively stop corrosive species from reaching the metallic substrate. Thus, a review on the evolution of LDH materials made on the anodic films of Mg alloys focusing in depth on corrosion performance by covering the recent evaluation perspectives, trends in the synthesis methods, a deep insight into the mechanism, and the structure-corrosion correlation is urgently required. To the best of our knowledge, a review discussing the aforementioned aspects has not been undertaken. In this review, therefore, a short overview of the synthesis methods, formation mechanisms, and processing factors that affect the crystallinity and morphology of LDH films as well as the challenges and opportunities of developing advanced LDH-based materials with improved corrosion performance are elaborated coherently.

\section{Synthesis of LDH Films on Anodized Mg Alloys}

To date, several methods have been utilized to produce $\mathrm{LDHs}$ on the $\mathrm{Al}, \mathrm{Mg}$, and $\mathrm{Ti}$ alloy substrates, such as the co-deposition method [36,37], hydrothermal process [38,39], steam coatings method [40,41], electrodeposition [42], etc. These techniques were highlighted recently by Tabish et al. [43] and Guo et al. [44]. However, the methods that are usually employed to fabricate LDH films on the anodic films of Mg alloys are hydrothermal treatment and the co-precipitation method or a combination of both methods. Additional procedures, such as anion exchange reaction, and LDH reconstruction can be used to modify the LDH films to improve the protective properties of the LDH-based composites [43].

\subsection{Co-Precipitation Method}

Generally, LDHs can be fabricated by immersion of the anodic films of Mg alloys in a solution containing a selected ratio of divalent and trivalent metallic salts in the presence of the desired interlayer anion. Based on the type of metallic ions, the $\mathrm{pH}$ of the reaction medium during the synthesis process is usually controlled to be in the range of 7-11. However, several problems, such as the weak adhesion strength between the LDH film and the underlying substrate, complexity, time-consuming, low crystallization, and formation of large amounts of waste would be the main drawbacks of the co-precipitation method [43].

\subsection{In Situ Hydrothermal Treatment}

This feasible method has been employed in many studies to prepare homogenous LDH films on the anodic films of Mg alloys. Briefly, LDHs film can be obtained by immersing the anodic film in an aqueous solution containing $\mathrm{NO}_{3}{ }^{-}$anions followed by hydrothermal treatment in a Teflon-lined autoclave at temperatures over $383 \mathrm{~K}$. It is important to point out that autoclave conditions would limit the industrial applications of these materials, in particular the transport applications. Moreover, it is worth mentioning that the absence of autoclave conditions leads to the development of LDH films in carbonated electrolytes and the $\mathrm{CO}_{2}$-containing environment owing to the high sorption ability of LDH towards $\mathrm{CO}_{2}$ [45-48]. This led to the formation of so-called "dead" $\mathrm{LDH}$ film in which the intercalation of corrosion inhibitors became very difficult owing to the high charge density of $\mathrm{CO}_{3}{ }^{2-}$ anions, reducing the smart protection property of the film [49].

\subsection{Anion Exchange}

The LDH films are usually subjected to anion-exchange reactions to intercalate new anions into the gallery of LDH films. Therefore, it can be considered as an indirect approach to modify the structure and composition of LDH films. Anions of corrosion inhibitors, such as vanadate $\left(\mathrm{VO}_{3}{ }^{-}\right)[50]$, and molybdate $\left(\mathrm{MoO}_{4}{ }^{2-}\right)$ [51] are usually intercalated into 
the LDH films formed on the anodic films of Mg alloys. The LDH films intercalated with corrosion inhibitors would have a dual function: (i) entrapment of corrosive species and (ii) a controlled liberation of corrosion inhibitors. To sum up, although significant advances are achieved in the fabrication of $\mathrm{LDH} /$ anodic film composites of $\mathrm{Mg}$ alloys, two main challenges should be considered. First, how to increase the low adhesion strength between LDH coating and anodic films. Second, the formation of LDH films that occurs usually under autoclave conditions would significantly limit the industrial applications of these materials.

\section{Transformation of Anodic Film to Layered Double Hydroxide (LDH) Film}

To date, two hypotheses have been proposed to describe the formation mechanism of LDH films. First, $\mathrm{Mg}(\mathrm{OH})_{2}$ would play a precursor role in $\mathrm{LDH}$ formation [52,53]. As reported earlier [52], the $\mathrm{Mg}(\mathrm{OH})_{2}$ was deposited with a layered structure, while $\mathrm{Al}(\mathrm{OH})_{3}$ caused amorphous filamentary agglomerates during the initial formation stage. Then, the tetrahedral coordination of $\mathrm{Al}$ atoms will be transformed into octahedral ones, which are features of the $\mathrm{LDH}$ film. Second, the precursor of $\mathrm{LDH}$ is $\mathrm{Al}(\mathrm{OH})_{3}$. Here, the amorphous colloidal $\mathrm{Al}(\mathrm{OH})_{3}$ was generated at the initial formation stage of $\mathrm{LDH}$ and then converted into crystallites of aluminum oxide hydroxide [54]. Besides the continuous incorporation of surrounding $\mathrm{Mg}^{2+}$ and $\mathrm{CO}_{3}{ }^{2-}$ ions, the integrated plate-like structure of LDH was obtained. In both hypotheses, however, the co-precipitation of $\mathrm{Al}(\mathrm{OH})_{3}$ and $\mathrm{Mg}(\mathrm{OH})_{2}$ would take place without the generation of polynuclear hydroxo complexes, and precipitates containing either $\mathrm{Al}(\mathrm{OH})_{3}$ or $\mathrm{Mg}(\mathrm{OH})_{2}$ were formed at the initial stage [52].

As postulated by Zhang et al. [55], the internal sources of $\mathrm{Mg}^{2+}$ and $\mathrm{Al}^{3+}$ cations required for the development of $\mathrm{LDH}$ films were attributed to the dissolution of both the anodic films and AZ31 Mg alloy substrate. Here, the AZ31 Mg alloy samples were anodized in an electrolytic solution comprising $\mathrm{NaAlO}_{2}$ and $\mathrm{NaOH}$ for $30 \mathrm{~min}$ at a voltage of $20 \mathrm{~V}$. The hydrothermal treatment of the anodized film in a solution of $0.1 \mathrm{M} \mathrm{NaNO}_{3}$ at $398 \mathrm{~K}$ in an autoclave led to the formation of LDH film. Based on the author's findings, a StranskiKrastanov (SK) two-dimensional layer growth (2D) to three-dimensional (3D) growth mode was suitable to elucidate the transformation from the anodic film to the $\mathrm{Mg}-\mathrm{Al} \mathrm{LDHs}$ film [55]. Figure 2 demonstrates the transformation process of the anodic film into LDH film. (I) An anodic film containing $\mathrm{MgAl}_{2} \mathrm{O}_{4}$, amorphous $\mathrm{MgO}$, and amorphous $\mathrm{Mg}(\mathrm{OH})_{2}$ can be made on the surface of AZ31 Mg alloy as a result of the anodizing process in the alkaline-aluminate electrolyte. (II) A layered structure tended to be formed by the gradual gathering of the amorphous $\mathrm{Mg}(\mathrm{OH})_{2} \cdot \mathrm{Mg}^{2+}$ cations resulting from the dissolution of the anodic film would combine with $\mathrm{OH}^{-}$anions, forming sphere-like aggregates $\mathrm{Mg}(\mathrm{OH})_{2}$ with a layered structure [56]. This would lead to covering the micropores of the anodic film, resulting in the formation of a smooth surface. (III) The AZ31 Mg alloy substrate would also dissolve upon increasing the hydrothermal treatment time which resulted in a considerable increase in $\mathrm{pH}$ of the hydrothermal solution. The main reactions that happened during the LDH film formation can be summarized as follows:

$$
\begin{gathered}
\mathrm{Mg}+\mathrm{H}^{+}+\mathrm{H}_{2} \mathrm{O} \rightarrow \mathrm{Mg}^{2+}+\mathrm{OH}^{-}+\mathrm{H}_{2} \uparrow \\
\mathrm{Mg}^{2+}+2 \mathrm{OH}^{-} \rightarrow \mathrm{Mg}(\mathrm{OH})_{2} \downarrow
\end{gathered}
$$




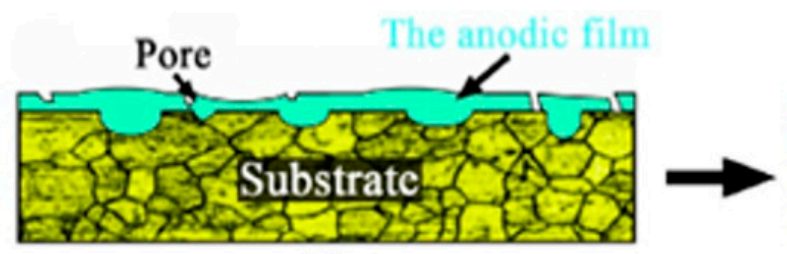

(I)

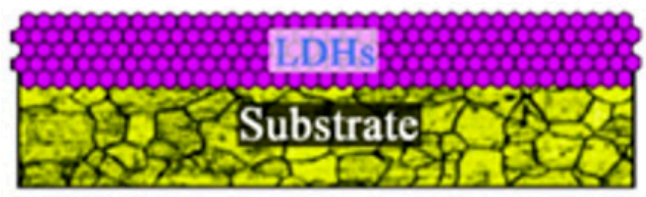

(V)

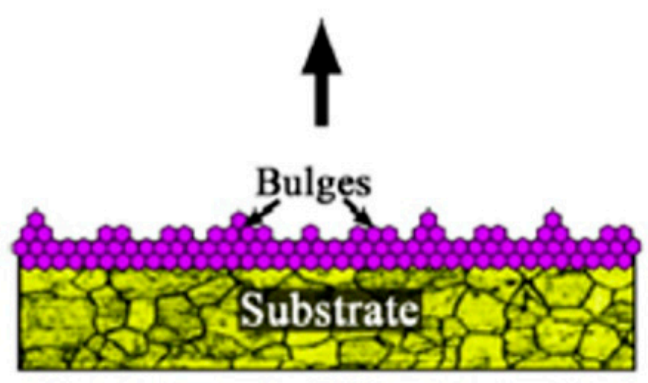

(IV)

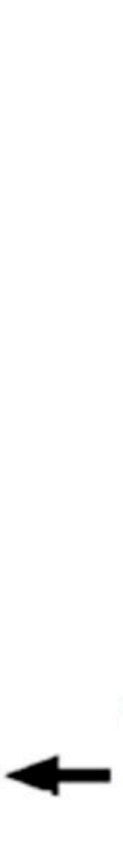

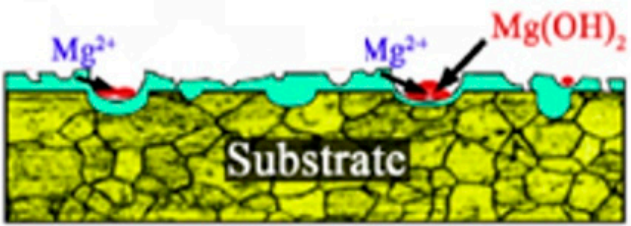

(II)

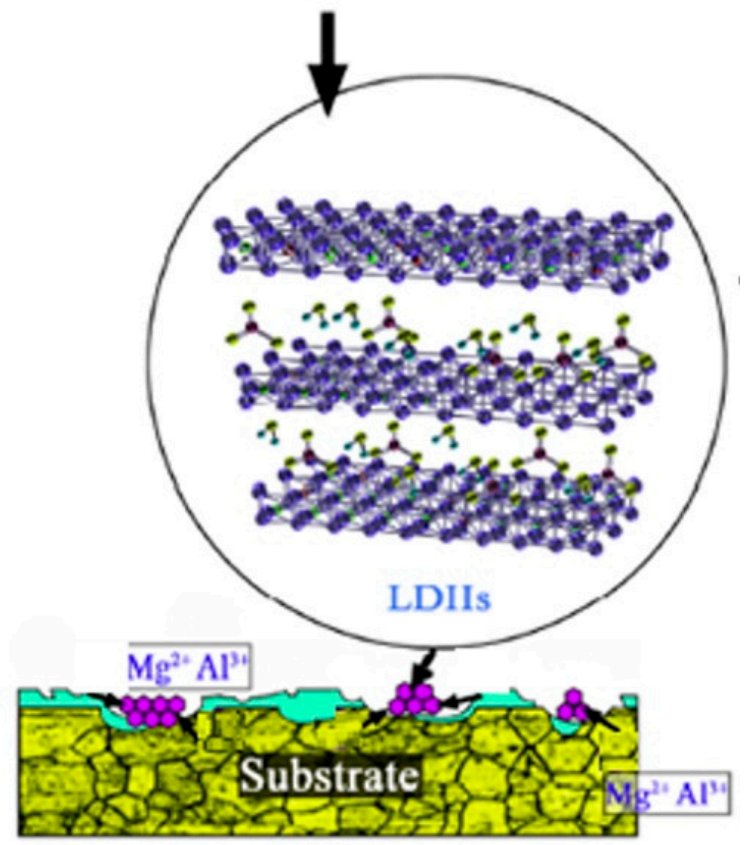

(III)

Figure 2. Schematic diagram of the transformation process of anodized film into LDH film. Reprinted with permission from ref. [55]. Copyright 2018 Elsevier.

Here, inwards growth of the LDHs film would happen as a result of the dissolution of AZ31 Mg alloy substrate and formation of $\mathrm{Mg}(\mathrm{OH})_{2}$. At the same time, $\mathrm{Al}^{3+}$ cations tended to incorporate into $\mathrm{Mg}(\mathrm{OH})_{2}$ structure which caused an imbalance in the sheet structure and the breaking down of the hydrogen bonds [54]. Thus, $\mathrm{NO}_{3}{ }^{-}$inions tended to intercalate between the layers to maintain charge balance. (IV) At this point, LDH film grows inwards to the substrate and outwards to the film/solution interface simultaneously. As for the outwards growth, the LDH film would cover the entire surface accompanied by the formation of some sphere-like structures. Since the formation of islands would lower the strain energy in the crystals, their formation was energetically favorable. Thus, the growth model was transformed from 2D to 3D growth mode. (V) The crystallinity and thickness of LDH film tended to increase with time until the complete depletion of $\mathrm{Mg}^{2+}$ and $\mathrm{Al}^{3+}$ cations in the solution. Finally, it is worthwhile pointing out that the novel method of preparing $\mathrm{Mg}-\mathrm{Al} \mathrm{LDH}$ described above has been also applied to describe the growth of LDH films on PEO coatings and to study the effect of PEO properties on the growth of LDHs $[57,58]$.

\section{Corrosion Performance of LDH/Anodic Film Composites}

Growing LDH films on the surface of anodic films obtained by either anodizing or the PEO process would have several advantages as compared to the LDHs film fabricated directly on the $\mathrm{Mg}$ alloy substrate. First, the LDH film can adhere well to the anodic film. Second, the sealing of structural defects in the anodic film by the LDH films would provide a strong physical layer against the corrosive anions attack. Third, the intercalation of 
LDH film with corrosion inhibitors anions, such as $\mathrm{MoO}_{4}{ }^{2-}$ and $\mathrm{VO}_{3}{ }^{-}$would lead to the development of smart self-healing films with excellent protective properties.

\subsection{Conventional Anodizing}

LDH films are usually made on the anodized films of AZ31 and AZ91 Mg alloys that are generated by anodizing a solution containing $\mathrm{NaOH}$ and $\mathrm{NaAlO}_{2}$ at a voltage below $80 \mathrm{~V}$. Here, the anodic films would supply sufficient $\mathrm{Mg}$ and $\mathrm{Al}$ mixed oxides to fabricate LDH films. Briefly, the anodic film obtained by the anodization of $\mathrm{Mg}$ alloy substrate in a suitable electrolyte could be exploited as internal sources of $\mathrm{M}^{2+}$ and $\mathrm{M}^{3+}$ cations which eliminate the need to add extra metal salts. Such a procedure would lead to the development of dense and uniform LDH film with good corrosion protection properties [59]. Following this approach, Zhang et al. [50] prepared a mixed oxide of $\mathrm{Mg}$ and $\mathrm{Al}$ through the anodizing of AZ31 Mg alloy in a solution comprising $\mathrm{NaOH}$ and $\mathrm{NaAlO}_{2}$. The voltage and anodizing time were controlled to be $20 \mathrm{~V}$ and $30 \mathrm{~min}$, respectively. Such an anodic film would be the source of cations required for the preparation Mg-Al LDHs film. In other words, there would be no need to add any trivalent metallic salts during the synthesis of $\mathrm{LDH}$ film. Also, $\mathrm{VO}_{3}{ }^{-}$anions were loaded into the $\mathrm{LDH}$ film through an anion-exchange reaction in a solution containing $0.1 \mathrm{M} \mathrm{NH}_{4} \mathrm{VO}_{3}$. Here, $\mathrm{LDH}-\mathrm{NO}_{3}$ describes the $\mathrm{LDH}$ film produced on the anodized film of AZ31 Mg alloy while $\mathrm{LDH}-\mathrm{VO}_{3}$ film refers to the $\mathrm{LDH}$ film subjected to an ion-exchange reaction. As shown in Figure $3 a-c$, the formation of $\mathrm{LDH}-\mathrm{NO}_{3}$ and $\mathrm{LDH}-\mathrm{VO}_{3}$ films led to an increase in the uniformity of the anodized film by blocking the micropores where a considerable change in the morphology of the anodized film was observed after the sealing treatment by LDH films (insets in Figure 3a-c). According to energy-dispersive X-ray spectroscopy (EDS) analysis performed at three different positions $(1,2$, and 3$), \mathrm{Mg}, \mathrm{Al}$, and $\mathrm{O}$ elements were identified in all films while $\mathrm{V}$ element was detected only in the $\mathrm{LDH}-\mathrm{VO}_{3}$ film due to the ion-exchange reaction. The formation of $\mathrm{LDH}-\mathrm{NO}_{3}$ film on the surface of the anodized film was confirmed by the X-ray diffraction (XRD) patterns where two reflections of (003) and (006) were identified at $11.28^{\circ}$ and $23.46^{\circ}$, respectively (Figure 3d). After the formation of $\mathrm{LDH}-\mathrm{VO}_{3}$ film by an anion-exchange reaction, the two characteristic reflections of (003) and (006) were shifted to lower angles of $10.90^{\circ}$ and $22.96^{\circ}$, respectively, suggesting the intercalation of the $\mathrm{VO}_{3}{ }^{-}$anions into the interlayer galleries of $\mathrm{LDH}$. Figure 3 e shows the potentiodynamic polarization (PDP) of the samples in a $3.5 \mathrm{wt} . \% \mathrm{NaCl}$ solution. The results of PDP tests showed that the values of $E_{\text {corr }}$ of $\mathrm{AZ} 31 \mathrm{Mg}$ substrate, anodized substrate, $\mathrm{LDH}-\mathrm{NO}_{3}$ film, and $\mathrm{LDH}-\mathrm{VO}_{3}$ film were $-1.45 \mathrm{~V},-0.74 \mathrm{~V},-0.47$, and $-0.40 \mathrm{~V}$ vs. saturated calomel electrode (SCE), respectively while the corresponding corrosion current density $\left(i_{\text {corr }}\right)$ were $1.23 \times 10^{-5}$, $3.89 \times 10^{-6}, 9.48 \times 10^{-7}$, and $2.48 \times 10^{-7} \mathrm{~A} \cdot \mathrm{cm}^{-2}$, respectively. As a result, $\mathrm{LDH}^{-\mathrm{VO}_{3}}$ film exhibited the lowest corrosion rate as this film had the smallest value of $i_{\text {corr }}$ and the noblest value of corrosion potential $\left(E_{\text {corr }}\right)$. This result was confirmed by the stable morphology of $\mathrm{LDH}_{-}-\mathrm{VO}_{3}$ film after $144 \mathrm{~h}$ of immersion in $3.5 \mathrm{wt} . \% \mathrm{NaCl}$ solution. The sealing effects originated from the disposition of $\mathrm{LDH}$ flakes and vanadium-rich oxide on the porous surface of the anodized film would be responsible for such improvements in corrosion resistance [50]. 

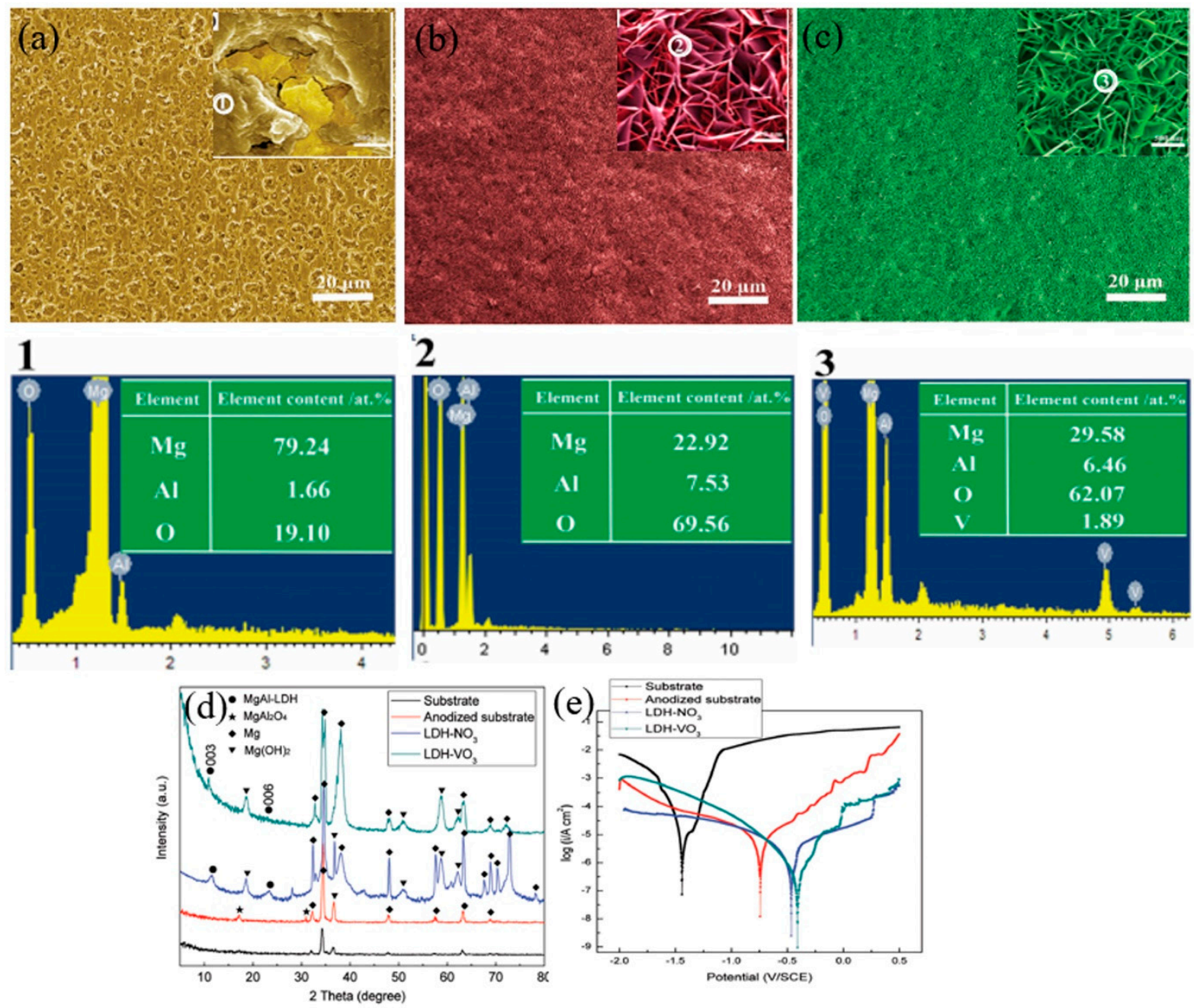

Figure 3. $(\mathbf{a}-\mathbf{c})$ Scanning electron microscopy (SEM) images showing the surface morphologies and the corresponding energy-dispersive X-ray spectroscopy (EDS) analysis of three different positions (1,2, and 3) of the anodized sample, $\mathrm{LDH}-\mathrm{NO}_{3}$ film, and $\mathrm{LDH}-\mathrm{VO}_{3}$ film, receptively. The insets (scale bare $=500 \mathrm{~nm}$ ) in Figure $3 \mathrm{a}-\mathrm{c}$ represent the corresponding high-magnification images. (d) X-ray diffraction (XRD) patterns of the substrate, anodized sample, $\mathrm{LDH}^{-\mathrm{NO}} \mathrm{O}_{3}$ film, and $\mathrm{LDH}-\mathrm{VO}_{3}$ film. (e) Potentiodynamic polarization (PPD) curves of the substrate, anodized sample, $\mathrm{LDH}_{-} \mathrm{NO}_{3}$ film, and $\mathrm{LDH}-\mathrm{VO}_{3}$ film in 3.5 wt.\% NaCl solution. Adapted with permission from ref. [50]. Copyright 2017 John Wiley and Sons.

Wu et al. [60] studied the corrosion performance of superhydrophobic films on the anodized AZ31 Mg alloy modified with 1H, 1H, 2H, 2H-perfluorodecyltrimethoxysilane $\left(\mathrm{C}_{10} \mathrm{H}_{4} \mathrm{Cl}_{3} \mathrm{~F}_{17} \mathrm{Si}\right)$ (PFDTMS), stearic acid (SA), sodium laurate (SL), and myristic acid (MA), respectively. The results demonstrated that the modification by PFDTMS could produce a better barrier to improve the corrosion resistance of AZ31 Mg alloy than the fatty acid with long carbon chains due to the formation of the $\mathrm{Si}-\mathrm{O}$-surface bond by a condensation polymerization reaction. Similarly, the in situ deposition of $\mathrm{Mg}-\mathrm{Al} \mathrm{LDHs}$ film on the anodized AZ31 Mg alloy followed by a modification by either MA or PFDTMS was examined by Zhang and co-workers [61]. LDHs with the biggest flakes were found to be the favorite adsorption sites for MA, while unfavorable for the adsorption of PFDTMS. The corrosion assessments in a $3.5 \mathrm{wt} . \% \mathrm{NaCl}$ solution revealed that the super-hydrophobic $\mathrm{Mg}-\mathrm{Al} \mathrm{LDH}$ films obtained by intercalating MA showed higher corrosion resistance than the counterparts modified by PFFDTMS.

Very recently, $\mathrm{Wu}$ and coworkers [62] prepared a Ce-doped $\mathrm{Mg}-\mathrm{Al} \mathrm{LDH}$ film on the surface of anodized AZ31 Mg alloy by a hydrothermal treatment while $\mathrm{VO}_{3}{ }^{-}$anions were loaded to $\mathrm{LDH}$ film via an ion-exchange reaction. The anodized samples were placed in a solution consisted of $\mathrm{Al}\left(\mathrm{NO}_{3}\right)_{3} \cdot 6 \mathrm{H}_{2} \mathrm{O}, \mathrm{Ce}\left(\mathrm{NO}_{3}\right)_{3} \cdot 6 \mathrm{H}_{2} \mathrm{O}$, and $\mathrm{NH}_{4} \mathrm{NO}_{3}$. The immersion 
time, temperature, and pH were controlled to be 12 h, $398 \mathrm{~K}$, and 10.8, respectively. To intercalate $\mathrm{VO}_{3}{ }^{-}$anions, the samples immersed in the above solution were immersed additionally in the solution of $0.1 \mathrm{M} \mathrm{NaVO}_{3}$ for $2 \mathrm{~h}$ at $45^{\circ} \mathrm{C}$ at a $\mathrm{pH}$ of 8.4 . The results indicated that a uniform and compact $\mathrm{LDH}$ film was obtained and the intercalation of $\mathrm{Ce}^{3+}$ and $\mathrm{VO}_{3}{ }^{-}$ions would change the crystal structure of LDHs. As a result of the loading of $\mathrm{Ce}$ and $\mathrm{VO}_{3}{ }^{-}$ions into the $\mathrm{LDH}$ film, the corrosion of the film was greatly suppressed, suggesting the co-intercalation of corrosion inhibitors into LDH film provided an effective method to protect AZ31 Mg alloy from corrosion attack.

Wu et al. and co-workers in other works $[50,55,63]$ successfully sealed the anodized AZ31 Mg alloy by LDHs films. AZ31 Mg alloy samples were oxidized in a solution of $7.14 \mathrm{~g} / \mathrm{L} \mathrm{NaOH}$ and $4 \mathrm{~g} / \mathrm{L} \mathrm{NaAlO}_{2}$ for $30 \mathrm{~min}$ at a voltage of $20 \mathrm{~V}$. Afterward, $\mathrm{Mg}-\mathrm{M}$ $(\mathrm{M}=\mathrm{Al}, \mathrm{Cr}$, and $\mathrm{Fe}$ ) LDH films were fabricated by placing the anodized samples in an aqueous solution composed of $0.05 \mathrm{M} \mathrm{M}\left(\mathrm{NO}_{3}\right)_{3}$ and $0.3 \mathrm{M} \mathrm{NH}_{4} \mathrm{NO}_{3}$ at $398 \mathrm{~K}$ for $12 \mathrm{~h}$. The results indicated that the porous anodized film was completely sealed by LDH flakes. The electrochemical impedance spectroscopy (EIS) results revealed that the corrosion resistance ranked as follows: $\mathrm{Mg}-\mathrm{Al} \mathrm{LDH}>\mathrm{Mg}-\mathrm{Fe} \mathrm{LDH}>\mathrm{Mg}-\mathrm{Cr} \mathrm{LDH}>$ anodized AZ31 > AZ31substrate [63]. Two factors were responsible for the enhancement of protective properties of the anodized samples after the formation of LDH films. Firstly, the LDH films would completely seal the structural defects of the anodic film which hindered the corrosive species from reaching the substrate. Secondly, the LDH film as a nanocontainer has an excellent ion-exchange capability which enables the controlled liberation of corrosion inhibitors. Two such factors are summarized in the corrosion protection mechanism illustrated in Figure 4. In the proposed corrosion protection mechanism, four layers from top to the bottom, such as the diffusion boundary layer, the LDH film, the anodic film, and the AZ31 substrate, can be identified. Thus, the improved protective properties would be attributed to the ion-exchange capability, deposition of $\mathrm{Mg}(\mathrm{OH})_{2}$, and synergistic protection with anodic film.

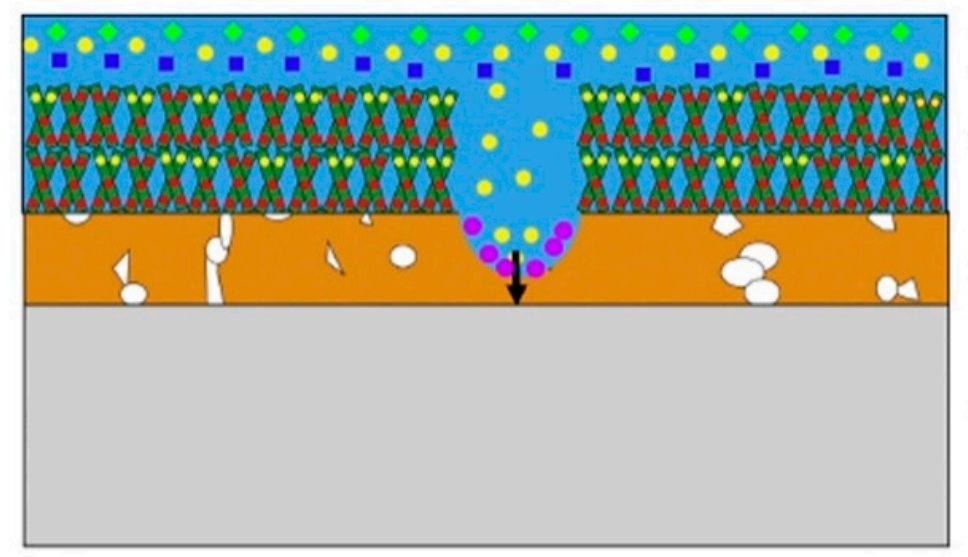

\section{Diffusion boundary layer The LDH film} The anodic film

\section{The AZ31substrate}

\section{$\mathrm{Cl}^{-} \cdot \mathrm{NO}_{3}^{-} \cdot \mathrm{Mg}(\mathrm{OH})_{2} \cdot \mathrm{Mg}^{2+} \cdot \mathrm{OH}^{-}$}

Figure 4. The proposed corrosion protection mode for the LDH/anodic film composite. Reprinted with permission from ref. [63]. Copyright 2018 Elsevier.

As stated by Zhang et al. [55], a uniform and smooth surface could be formed on the surface of the anodized AZ31 Mg alloy as a result of increasing the hydrothermal treatment time from $0.5 \mathrm{~h}$ to $12 \mathrm{~h}$ during the synthesis process of LDH film. The compositional analysis results confirmed the formation of the LDH films. It was found that the morphologies of the LDH films formed on anodized AZ31 Mg alloys were found to be uniform and smooth. Consequently, the protective properties were significantly improved as approved by EIS and PDP measurements in a $3.5 \mathrm{wt} . \% \mathrm{NaCl}$ solution. 
The mechanism of the in situ formation of LDH films on the anodized film of AZ31 $\mathrm{Mg}$ alloy was proposed by Wu et al. [64]. The substrate was first anodized in an alkalinealuminate solution, resulting in the formation of a porous anodic film, on which the LDH nuclei were directly produced. Under specific conditions, the nuclei gradually grew up, and then altered into the nanosheets, which assembled to make the LDH films. Such a conversion was greatly affected by the $\mathrm{pH}$ of the solution which played a crucial role in the generation of the LDHs film. The films obtained at the $\mathrm{pH}$ of 12.04 showed lower crystallinity of LDH nuclei and lower generation of the $\mathrm{Mg}-\mathrm{Al} \mathrm{LDH}$ films because the excessive $\mathrm{OH}^{-}$would obstruct the reaction process from $\mathrm{Mg}^{+}$to $\mathrm{Mg}^{2+}$, leading to a significant decrease in $\mathrm{Mg}^{2+}$ concentration which, in turn, restricts the generation of $\mathrm{Mg}_{5}\left(\mathrm{CO}_{3}\right)_{4}(\mathrm{OH})_{2} \cdot 5 \mathrm{H}_{2} \mathrm{O}$. As a result, the pores remain on the anodized sample, leading to poor corrosion resistance. In contrast, the films made in the $\mathrm{pH}$ between 10.72 and 11.72 exhibited a higher crystallinity of LDH flakes which resulted in high densification of the LDH structure. Such LDH films, therefore, could successfully seal the structural defects of the anodic films and reduce the corrosion rate of the AZ31 Mg alloy substrate.

In another work, Wu et al. [65] examined the correlation between the reaction temperature and the growth of $\mathrm{Mg}-\mathrm{Al} \mathrm{LDH}$ film fabricated on the anodized AZ31 Mg alloy via the in situ hydrothermal treatment method. Four different temperatures, such as 378, $388,398,408$, and $418 \mathrm{~K}$ were used during the hydrothermal treatment. When $\mathrm{T}=378 \mathrm{~K}$ and $388 \mathrm{~K}$, the holes of the films of samples are larger and obvious; while $\mathrm{T}=398 \mathrm{~K}$, there are just some bumps on the surface; when $\mathrm{T}=408 \mathrm{~K}$ and $418 \mathrm{~K}$, the bumps were observed obviously from the surface of samples. The result revealed that the crystallinity of LDHs tended to improve with an increase in the reaction temperature. The results of the PDP tests in the corrosive medium implied that the values of $E_{\text {corr }}$ of LDH-378 K, LDH-388 K, LDH-398 K, LDH-408 K, and LDH-418 K were $-1.278 \mathrm{~V},-0.807 \mathrm{~V},-0.701 \mathrm{~V},-0.588 \mathrm{~V}$, and $-0.318 \mathrm{~V}$ vs. SCE, respectively while the corresponding $i_{\text {corr }}$ were $19.36,1.459,2.157$, 2.199 , and $1.036 \mu \mathrm{A} \cdot \mathrm{cm}^{-2}$, respectively. Consequently, the LDH film obtained at $418 \mathrm{~K}$ had a higher corrosion resistance than other LDHs films. Using a solution composed of $\mathrm{NaNO}_{3}$ with $0.004,0.032$, and $0.256 \mathrm{M}$ of $\mathrm{Al}\left(\mathrm{NO}_{3}\right)_{3}$, the same research group successfully in situ deposited $\mathrm{Mg}-\mathrm{Al} \mathrm{LDH}$ films on the anodized AZ31 Mg alloy samples [66]. The anodized AZ31 $\mathrm{Mg}$ alloy samples were immersed in the above solution $(\mathrm{pH}=9)$ for $12 \mathrm{~h}$ at $398 \mathrm{~K}$. The results indicated that $\mathrm{LDH}$ films obtained with a $0.032 \mathrm{M} \mathrm{Al}\left(\mathrm{NO}_{3}\right)_{3}$ solution had good crystallinity with higher impedance value, providing efficient protection for the anodized AZ31 Mg alloy substrate.

A novel method without adding extra salts during the formation of LDH film was proposed by Zhang et al. [67] who examined the influence of the sealing by boiling water on the growth and corrosion resistance of $\mathrm{Mg}-\mathrm{Al} \mathrm{LDH}$ film made on anodized AZ31 Mg alloy. For this reason, the anodized AZ31 $\mathrm{Mg}$ alloy samples were first treated by boiling water for $20 \mathrm{~min}$ and then by hydrothermal treatment in distilled water at $398 \mathrm{~K}$ for $12 \mathrm{~h}$ under autoclave conditions. Here, "A" refers to the anodized film, "AS" refers to the anodized film sealed by boiling water, "A-LDH" describes the LDH film formed directly on the anodized film, while "AS-LDH" indicates the LDH film formed on the sealed anodized film. The results presented in Figure $5 \mathrm{a}-\mathrm{d}$ showed that the porous anodized film tended to be sealed by the LDH film where a fine and compact LDH film was formed when the anodized sample was sealed by boiling water before the sealing by LDH. This result would be ascribed to the fact that the anodized film during the sealing treatment by boiling water would have high kinetic energy and reactivity. Accordingly, the amorphous $\mathrm{Mg}(\mathrm{OH})_{2}$ gradually gathers in blocks to form the LDH structure. The presence of a high nuclei density in a given area would prevent the growth of individual particles in 2 dimensions, leading to the development of a film layer comprising numerous $\mathrm{Mg}(\mathrm{OH})_{2}$ crystallites in the nano-size range. Owing to the fine and compact morphology of the LDHs film made on the sealed anodized film, therefore, the AS-LDH sample exhibited a superior corrosion resistance in comparison to other samples. 

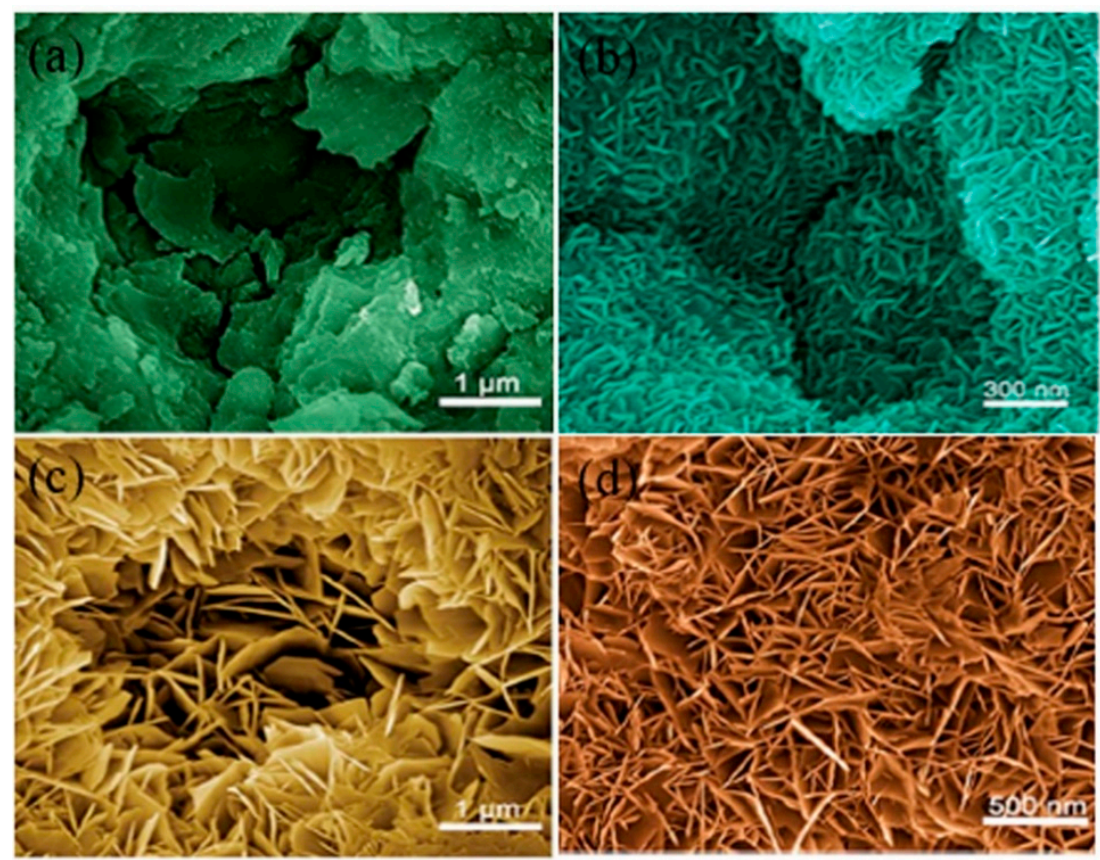

Figure 5. (a-d) SEM images showing the surface morphologies of the "A" (anodized film), "As" (anodized film sealed by boiling water), "A-LDH" (LDH film formed directly on the anodized film), and "AS-LDH" (LDH film formed on the sealed anodized film), respectively [67].

\subsection{Plasma Electrolytic Oxidation (PEO) Coating}

In general, PEO may provide several advantages over anodizing, such as higher adhesion strength, high hardness, higher thickness, as well as the formation of crystalline phases under plasma conditions $[7,12,68]$. However, the structural defects formed inevitably during the PEO process would facilitate the inward motion of the corrosive medium into the substrate. In this regard, the sealing of such structural defects by the inclusion of nano-particles to the electrolyte during PEO or by using the post-treatments by boiling water, organic compounds, and sol-gel films have been proposed by several research groups [67-77]. Similar to the anodized samples, the successful formation of the LDHs on the PEO-coated samples not only caused an effective sealing of the structural defects but also released the corrosion inhibitors, providing the function of self-healing properties [19,43,78-83].

\subsubsection{Correlation between the Dissolution Rate of PEO and Growth of LDH}

The elevated temperatures associated with the formation of PEO-LDH composite coatings would lead to a mismatch between the dissolution of PEO layers and the growth of Mg-Al LDH film [84-89]. This deficiency would restrict the large improvement in the protective properties of these materials. To fabricate a composite coating with superior corrosion performance, therefore, the dissolution rate of the PEO coating must be far slower than the growth rate of the LDH film. Thus, it is challenging and difficult to discover the equilibrium point between the dissolution rate of the PEO coating and the growth rate of the LDH film. Here, three cases can be discussed based on the dissolution rate of PEO coating and LDH film. First, if the dissolution rate of the PEO coating is greater than the growth rate of the LDH film, the protective properties of the composite coating may be limited. For instance, Chen et al. [84] used a hydrothermal treatment method in a $0.1 \mathrm{M}$ $\mathrm{Al}\left(\mathrm{NO}_{3}\right)_{3}$ and $0.6 \mathrm{M} \mathrm{NH}_{4} \mathrm{NO}_{3}$ solution at $368 \mathrm{~K}$ with a $\mathrm{pH}$ of 7 for $1 \mathrm{~h}$ to prepare $\mathrm{Mg}-\mathrm{AL}$ $\mathrm{LDH}$ on the PEO coating of AZ31 Mg alloy. The results revealed that a low $\mathrm{pH}$ value resulted in cracking in the PEO coating. The $i_{\text {corr }}$ of the composite coating instead increased one order of magnitude that of the PEO coating, which demonstrated that the corrosion resistance of the hybrid coating cannot reach the as-expected target. The authors also 
prepared different LDH films, such as $\mathrm{Zn}-\mathrm{Mg} \mathrm{LDH}, \mathrm{Ni}-\mathrm{Mg} \mathrm{LDH}$ films, and compared the corrosion results with the $\mathrm{Mg}-\mathrm{Al} \mathrm{LDH}$ film and single $\mathrm{PEO}$ coating. They claimed that the type of cation loading LDH film played a key role in the protective properties of the composites. The Ni-Mg LDH film showed the highest corrosion resistance in comparison to other films because the porous structure of the PEO coating was completely sealed by the flakes of this film. In contrast, the $\mathrm{Zn}-\mathrm{Mg} \mathrm{LDH}$ film showed inferior improvement in the corrosion resistance as only a small number of micropores of original PEO coating were sealed by this film. Second, if the dissolution rate of the PEO coating is identical to the growth rate of the LDH film, this may cause a certain improvement in the protective properties due to the partial sealing of structural defects of PEO coating by LDH films. As an example, Peng et al. [85] made a Mg-Al LDH film on the PEO-coated AZ31 Mg alloy by hydrothermal treatment at $293 \mathrm{~K}$ for $12 \mathrm{~h}$ using a solution with a $\mathrm{pH}$ of 12.8 . PDP results in a phosphate-buffered saline solution indicated that the $i_{\text {corr }}$ of the PEO coating was only reduced from $9.45 \times 10^{-6} \mathrm{~A} \mathrm{~cm}^{-2}$ to $3.92 \times 10^{-6} \mathrm{~A} \mathrm{~cm}^{-2}$ upon the application of $\mathrm{Mg}-\mathrm{Al}$ $\mathrm{LDH}$ film on the surface of PEO coating, suggesting a slight improvement in the corrosion resistance was achieved. Moreover, the cytocompatibility tests using rat bone marrow stem cells indicated that the PEO-LDH composite can be applied as a promising implant in orthopedic surgery as it has better cytocompatibility property in comparison to the single PEO coating.

Third, if the dissolution rate of the PEO coating is less than the growth rate of the LDH film, the protective properties of the composite coating will be enhanced. For instance, Jiang et al. [86] fabricated a Mg-Al LDH film on the PEO coating of AZ91 Mg alloy by co-precipitation and hydrothermal treatment for different periods, such as $8,20,36$, $48 \mathrm{~h}$ at $393 \mathrm{~K}$. The hydrothermal solution was composed of appropriate concentrations of $\mathrm{Mg}\left(\mathrm{NO}_{3}\right)_{2} \cdot 6 \mathrm{H}_{2} \mathrm{O}, \mathrm{Al}\left(\mathrm{NO}_{3}\right)_{3} \cdot 9 \mathrm{H}_{2} \mathrm{O}$, and $\mathrm{Na}_{2} \mathrm{MoO}_{4} \cdot 2 \mathrm{H}_{2} \mathrm{O}$. The findings suggested that the $i_{\text {corr }}$ decreased from $1.27 \times 10^{-6} \mathrm{~A} \mathrm{~cm}^{-2}$ for PEO coating to $1.03 \times 10^{-7} \mathrm{~A} \mathrm{~cm}^{-2}$ for PEO-LDH film, which shows an increased corrosion resistance. Moreover, a selfhealing capability with active inhibition ability of AZ91 Mg alloy was observed through the modification of the $\mathrm{LDH}$ film loaded with $\mathrm{MoO}_{4}{ }^{2-}$ anions by fluoroalkyl silane and infusion of perfluoropolyether treatments.

Chen et al. [87] successfully grew Mg-Fe LDH film on the surface of PEO coating of AZ31 Mg alloy via hydrothermal treatment in a solution containing appropriate concentrations of $\mathrm{Fe}\left(\mathrm{NO}_{3}\right)_{3} \cdot 9 \mathrm{H}_{2} \mathrm{O}$ and $\mathrm{NH}_{4} \mathrm{VO}_{3}$ at $398 \mathrm{~K}$ for $24 \mathrm{~h}$ using an autoclave reactor. They found that the structural defects of PEO coating would act as ideal sites for the growth of LDHs flakes. Since a slight decrease in the thickness of the PEO coating was observed after the formation of LDH film, the authors postulated that the formation of strong adhesion between the PEO and LDH film would be strongly affected by the dissolution rate of PEO coating. However, the PEO/LDHs composite coating showed better corrosion resistance as compared to the single PEO coating.

According to $\mathrm{Li}$ and co-workers [88], an extremely thin $\mathrm{Mg}(\mathrm{OH})_{2}$ film was prepared using in situ growth on PEO-coated Mg alloy AZ31. It is worth noting that it has a lower preparation temperature at $333 \mathrm{~K}$ and a higher $\mathrm{pH}$ of 13.60 . The composite coating has good corrosion resistance, and its $i_{\text {corr }}$ decreased three orders of magnitude than that of the substrate. This result implied that the growth rate of the $\mathrm{Mg}(\mathrm{OH})_{2}$ was greater than the dissolution rate of the PEO coating.

Following this approach, the same research group [89] suggested that the synthesis of LDH film on the surface of PEO-coated AZ31 Mg alloy can be successfully performed when the PEO coating was immersed in a solution containing EDTA-2Na and $\mathrm{NaOH}$ for $48 \mathrm{~h}$ at a relatively low temperature of $333 \mathrm{~K}$ which led to slow down the dissolution rate of PEO coating in comparison to the growth rate of the LDH film. As compared to the morphology of the PEO coating and PEO/LDH composite coating shown in Figure 6a,b, the PEO-LDH composite coating possessed self-healing ability whereby no cracks are observed on the surface of the composite coating even after $154 \mathrm{~h}$ of immersion in Hank's solution, as shown in Figure 6d. Furthermore, the authors attributed the development of cracks on the 
surface of AZ31 Mg alloy and PEO to the dehydration in field-emission scanning electron microscopy (FESEM) and not due to the immersion in Hank's solution. The Bode plots of the PEO coating and PEO/LDH composite coating are shown in Figure 6e,f. The impedance values $|\mathrm{Z}|$ at a frequency of $0.01 \mathrm{~Hz}$ of the $\mathrm{AZ31} \mathrm{Mg}$ alloy substrate, PEO coating, and $\mathrm{PEO} / \mathrm{LDH}$ composite were found to be $478.03,6.46 \times 10^{4}$, and $3.45 \times 10^{6} \Omega \cdot \mathrm{cm}^{2}$. The Bode phase angle plots shown in Figure $6 \mathrm{f}$ showed that the PEO-LDH composite coating had the highest angle at the high-frequency region. As a result, significant improvements in the corrosion resistance of $\mathrm{Mg}$ alloy can be achieved by the combination of PEO and LDH coatings. Finally, it can be deduced that achieving a balance between the dissolution rate of the PEO coating and the growth rate of the $\mathrm{LDH}$ film by adjusting the $\mathrm{pH}$ and synthesis temperatures to higher and lower values, respectively, leading to the fabrication of a composite coating with superior corrosion performance.
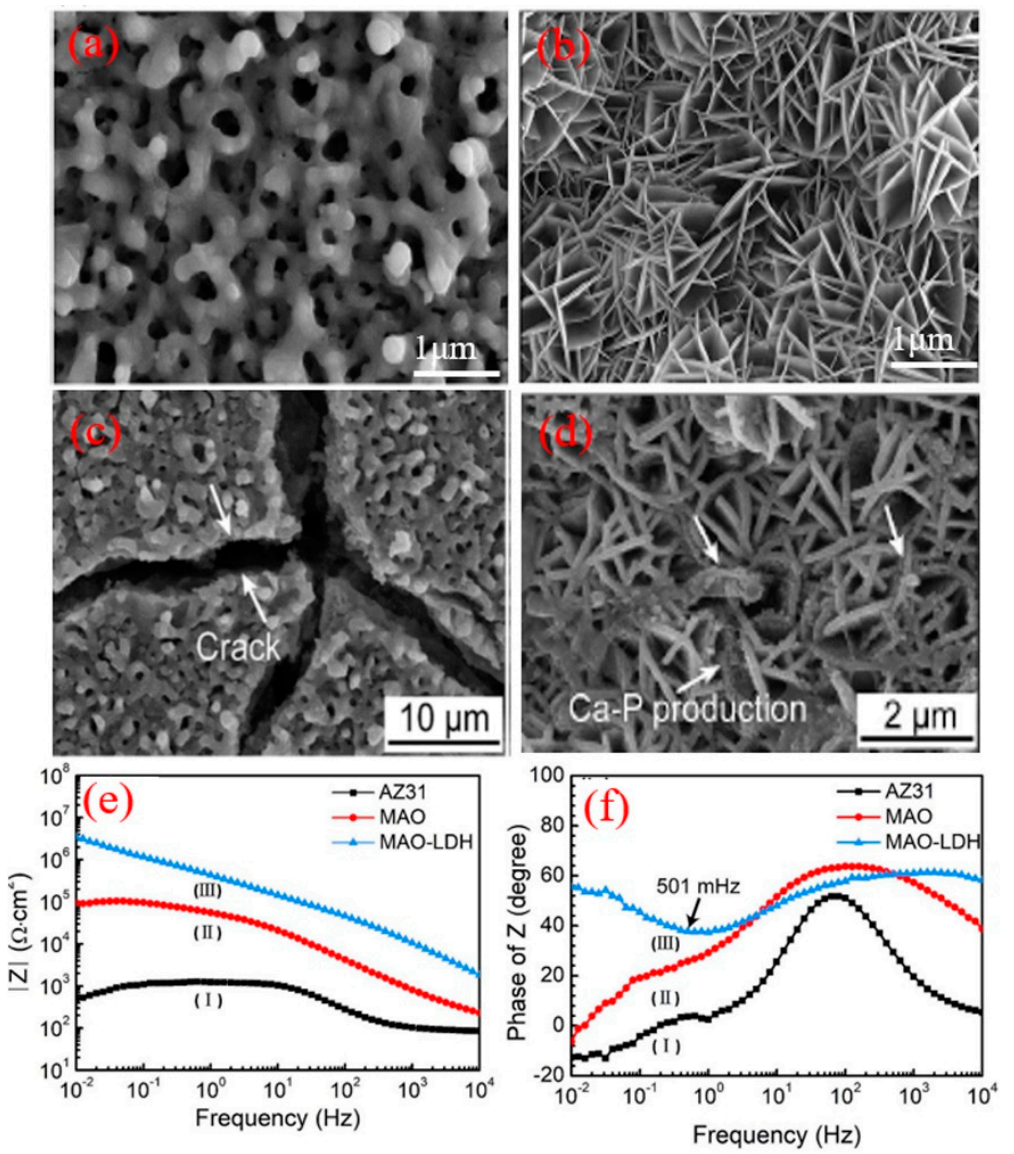

Figure 6. SEM images of the plasma electrolytic oxidation (PEO) coating and PEO-LDH composite coating before and after immersion for $154 \mathrm{~h}$ in $3.5 \mathrm{wt} . \% \mathrm{NaCl}$ solution where (a-c) PEO coating and (b,d) PEO-LDH coating. (e,f) represents the Bode plots of AZ31 Mg alloy substrate, PEO coating, and PEO-LDH coating, respectively [89].

\subsubsection{Modification of LDH Film Grown on PEO Coating}

The correlation between the voltage applied during the PEO treatment of AZ31 Mg alloy and the growth of the LDHs film was examined by Zhang et al. [58]. The AZ31 Mg alloy samples were treated in an alkaline-aluminate electrolyte under different voltages, such as 150, 200, 250, 300, and $350 \mathrm{~V}$ for $10 \mathrm{~min}$. Then, the LDH films were grown on the coated AZ31 Mg alloy samples via the hydrothermal method in a $0.1 \mathrm{M} \mathrm{NaNO}_{3}$ solution. The LDH growth was greatly affected by the dissolution rate of PEO coatings. The sample formed at $350 \mathrm{~V}$ showed a less number of $\mathrm{LDH}$ flakes which was attributed to the fact that $\mathrm{MgAl}_{2} \mathrm{O}_{4}$, which existed in higher amounts in the sample treated at $350 \mathrm{~V}$, had lower solubility than the other phases, such as $\mathrm{MgO}$ and $\mathrm{Al}_{2} \mathrm{O}_{3}$. Although the thickness of the 
LDH film made on the PEO sample treated at $350 \mathrm{~V}$ was not higher than other samples, this sample exhibited the best corrosion resistance which was attributed to synergistic effects between $\mathrm{LDH}$ film and stable $\mathrm{MgAl}_{2} \mathrm{O}_{4}$.

The correlation between the hydrothermal treatment time and the corrosion performance of LDH-PEO composite coating formed on $\mathrm{Mg}-\mathrm{Li}$ alloy was examined by Zhang et al. [90]. After the deposition of the coatings on $\mathrm{Mg}-\mathrm{Li}$ alloy samples via PEO utilizing an electrolyte composed of $\mathrm{NaOH}, \mathrm{Na}_{2} \mathrm{SiO}_{3} \cdot 9 \mathrm{H}_{2} \mathrm{O}$, and $\mathrm{NaF}$, the coated samples were placed in an aqueous solution $\mathrm{Al}\left(\mathrm{NO}_{3}\right)_{3} \cdot 9 \mathrm{H}_{2} \mathrm{O}$ for 12,18 , and $24 \mathrm{~h}$ at $363 \mathrm{~K} . \mathrm{NaOH}$ was added to adjust the $\mathrm{pH}$ value to be 12.4. The microstructural results revealed that the typical porous morphology of PEO coatings tended to be sealed by LDH sheets where a dense LDH film with a lamellar structure was formed on the PEO-coated sample immersed in the hydrothermal solution for $24 \mathrm{~h}$ at $363 \mathrm{~K}$. The compositional analysis of the coated samples approved the successful formation of LDH films on the surface of PEO coating which was mainly composed of $\mathrm{MgO}$ and $\mathrm{Mg}_{2} \mathrm{SiO}_{4}$. The authors attributed the formation of $\mathrm{LDH}$ film to the hydrothermal treatment which induces the partial dissolution of $\mathrm{MgO}$ which resulted in the deposition of $\mathrm{Mg}(\mathrm{OH})_{2}$ sheets, formed by the reaction of $\mathrm{OH}^{-}$anions with the released $\mathrm{Mg}^{2+}$ cations, on the surface of the PEO coating. Based on the hydrogen evolution analysis and weight loss assessments in a $3.5 \mathrm{wt} . \% \mathrm{NaCl}$ solution, it was established that the PEO coating had a higher corrosion rate than the PEO-LDH composite coating.

According to the recent study by Wang et al. [91], Mg-Al-Zn LDH films were successfully deposited on the PEO-coated $\mathrm{AZ} 31 \mathrm{Mg}$ alloy through a hydrothermal treatment in a solution of $0.05 \mathrm{M}$ of $\mathrm{Zn}\left(\mathrm{NO}_{3}\right)_{2} \cdot 6 \mathrm{H}_{2} \mathrm{O}$ without and with 0.01 and $0.05 \mathrm{M} \mathrm{Al}\left(\mathrm{NO}_{3}\right)_{3} \cdot 9 \mathrm{H}_{2} \mathrm{O}$ solution. The results revealed that the $\mathrm{MgO}$ which is the main component of $\mathrm{PEO}$ coating tended to dissolve partially under the hydrothermal treatment, liberating $\mathrm{Mg}^{2+}$ ions, which combined with $\mathrm{Al}^{3+}, \mathrm{Zn}^{2+}$, and $\mathrm{OH}^{-}$ions, forming $\mathrm{Mg}-\mathrm{Al}-\mathrm{Zn} \mathrm{LDH}$ films, which in turn act as a sealing agent to the porous morphology of PEO coating. Per PDP and EIS measurements in a $3.5 \mathrm{wt} . \% \mathrm{NaCl}$ solution, it was found that the formation of $\mathrm{LDH}$ film could greatly improve the corrosion resistance of PEO coating, regardless of the concentration of $\mathrm{Al}\left(\mathrm{NO}_{3}\right)_{3} \cdot 9 \mathrm{H}_{2} \mathrm{O}$. This result was ascribed to the filling effect and anion-exchange capacity of LDH films. Among different LDHs films, the protective properties of the LDH film made in a solution with a $0.05 \mathrm{M} \mathrm{Al}\left(\mathrm{NO}_{3}\right)_{3} \cdot 9 \mathrm{H}_{2} \mathrm{O}$ were superior to other cases which were reflected by the lower value of $i_{c o r r}$ and higher impedance value in PDP and Bode plots, respectively.

Peng et al. [92] prepared LDH film on Mg alloy via PEO and hydrothermal treatment techniques in a solution of $\mathrm{Al}\left(\mathrm{NO}_{3}\right)_{3}$ containing different concentrations of $\mathrm{Zn}\left(\mathrm{NO}_{3}\right)_{2}$, such as $0,10,100$, to $1000 \mu \mathrm{M}$. The samples obtained were denoted as $\mathrm{Mg}-\mathrm{Al} \mathrm{LDH}, \mathrm{Mg}-\mathrm{Zn} \# 1-\mathrm{Al}-$

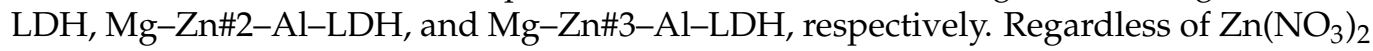
concentrations, the corrosion resistance of the AZ31 Mg alloy sample was improved by sealing the micropores of PEO coating with LDH flakes. Among all samples, Mg-Zn\#3Al-LDH sample exhibited the lowest corrosion rate as it had the lowest value of $i_{\text {corr }}$ and the highest value of polarization resistance $\left(R_{p}\right)$. Moreover, the Mg-Zn\#3-Al-LDH sample showed an improved osteogenic activity and antibacterial ability, suggesting the potential usage of this sample in implant applications.

Wang et al. [93] prepared a superhydrophobic coating on the surface of PEO-coated AZ31 Mg alloy through the surface modification of LDH film by stearic acid (SA). Put simply, the Mg-Al LDH films were prepared by a hydrothermal process by immersion PEO-coated samples in a solution composed of $\mathrm{Al}\left(\mathrm{NO}_{3}\right)_{3}$ at $398 \mathrm{~K}$ for 6, 12, 18, and $24 \mathrm{~h}$. The obtained samples were called PEO-LDH-6h, PEO-LDH-12h, PEO-LDH-18h, and PEOLDH-24h, respectively. The PEO-LDH-24h sample was immersed in an ethanol solution containing $0.05 \mathrm{M}$ of SA for $5 \mathrm{~h}$ at $333 \mathrm{~K}$. The sample obtained was called PEO-LDH24h/SA. The microstructural results revealed that the structural defects of PEO coating were gradually sealed by the growth of LDH flakes which tended to increase with an increase in the hydrothermal treatment time where a compact composite coating with a 
contact angle of $63.40^{\circ}$ was produced on the surface of PEO-LDH-24h. Interestingly, the modification by SA led not only to more densification of the LDH film but also resulted in the formation of a superhydrophobic composite coating with a contact angle of $151.21^{\circ}$. The electrochemical measurements in a $3.5 \mathrm{wt} . \% \mathrm{NaCl}$ solution revealed that the PEO-LDH$24 \mathrm{~h} / \mathrm{SA}$ sample had the highest corrosion resistance as compared to the substrate, PEO coating, and PEO-LDH-24h samples which were reflected by the highest impedance in the Bode plots. The improved corrosion resistance observed in the case of the PEO-LDH$24 \mathrm{~h}$ sample was attributed to the synergism between hydrophobicity property and the self-healing ability of LDH film.

Zhang [57] prepared LDH films on the PEO-coated AZ31 Mg alloy via hydrothermal treatment. Briefly, The PEO-coated sample was first subjected to a conversion coating using a solution containing $\mathrm{Ce}\left(\mathrm{NO}_{3}\right)_{3}$ and $\mathrm{H}_{2} \mathrm{O}_{2}$ for $2 \mathrm{~h}$ at $323 \mathrm{~K}$. This treatment led to the formation of a PEO-Ce sample. Afterward, the PEO-Ce sample was placed in $0.1 \mathrm{M}$ $\mathrm{NaNO}_{3}$ at $398 \mathrm{~K}$ for $12 \mathrm{~h}$ under autoclave conditions which led to the formation of the PEO-Ce-LDH sample. The PEO-Ce-LDH samples were subjected to an anion-exchange reaction using an aqueous solution of phytic acid (PA) at $353 \mathrm{~K}$ for $1 \mathrm{~h}$. The resultant sample was named PEO-Ce-LDH-P. The electrochemical measurements in a $3.5 \mathrm{wt} . \%$ $\mathrm{NaCl}$ solution indicated that the corrosion resistance of the PEO-Ce-LDH-P sample was superior to other samples which were linked to the synergistic effect between cerium and phosphate group from PA.

Recently, Kaseem and Ko [94] modified the surface of LDHs film made on the PEO coating of AZ31 Mg alloy. Here, the LDHs films, prepared by co-precipitation method using a solution of $\mathrm{Mg}\left(\mathrm{NO}_{3}\right)_{2}$ and $\mathrm{Al}\left(\mathrm{NO}_{3}\right)_{3}$ at $423 \mathrm{~K}$ with a $\mathrm{pH}$ of 10.5 , were modified by subsequent immersions in a solution containing albumin (ALB) molecules at $313 \mathrm{~K}$ for $1 \mathrm{~h}$ which lead to the formation of LDH-ALB film. The LDH was also immersed in a solution comprising of albumin and $\mathrm{WO}_{3}$ nanoparticles at $323 \mathrm{~K}$ for $2 \mathrm{~h}$ under continuous stirring which led to the formation of $\mathrm{LDH}-\mathrm{ALB}-\mathrm{WO}_{3}$ film. The results shown in Figure $7 \mathrm{a}-\mathrm{d}$, revealed that the deposition of ALB modified by $\mathrm{WO}_{3}$ nanoparticles could change the typical morphology of LDH film which led to the formation of a stable nest-like structure, hindering the penetration of corrosive anions through the film. From the PDP tests in a $3.5 \mathrm{wt} . \% \mathrm{NaCl}$ solution shown in Figure 7e,f, it was found that the LDH-ALB-WO $\mathrm{W}_{3}$ film had the lowest value of $i_{\text {corr }}$ and the most positive value of $E_{\text {corr }}$, suggesting that this film could effectively trap the corrosive anions which were linked to the high stability of the albumin- $\mathrm{WO}_{3}$ composite. Furthermore, the authors attributed the enhanced corrosion resistance of $\mathrm{LDH}-\mathrm{ALB}-\mathrm{WO}_{3}$ film to the semiconducting properties of the composite film which led to potential barrier generation at the interface, preventing ease of corrosive anions motion towards the substrate.

Zhang and coworkers [95] prepared Mg-Al LDH films through the hydrothermal treatment of the PEO-coated AZ31 Mg alloy and reported that the porosity of the PEO coating was decreased after in situ formation of the LDHs, and thereby, showed a significantly long period of protection for the substrate. An Mg-Al-Co LDH film was successfully prepared on PEO-coated AZ31 Mg alloy by in situ hydrothermal growth method [96]. Briefly, the PEO coated samples were placed in a solution containing $0.05 \mathrm{M} \mathrm{Al}\left(\mathrm{NO}_{3}\right)_{3}$ and $0.02 \mathrm{M}$ $\mathrm{Co}\left(\mathrm{NO}_{3}\right)_{2}$ for $24 \mathrm{~h}$ at $398 \mathrm{~K}$ under autoclave conditions. The $\mathrm{pH}$ solution was controlled to be 10.5 by adding ammonia. The results revealed that the surface of $\mathrm{Mg}-\mathrm{Al}-\mathrm{Co} \mathrm{LDH}$ made on PEO coating was more compact and uniform than the PEO coating, indicating that the flakes of LDH film sealed the micro-pores and cracks in the PEO coating completely. The formation of $\mathrm{Mg}-\mathrm{Al}-\mathrm{Co} \mathrm{LDH}$ film was attributed to the fact that the $\mathrm{Mg}^{2+}$ cations released by the gradual dissolution of the PEO coating tended to react with $\mathrm{Al}^{3+}, \mathrm{Co}^{2+}$, and $\mathrm{OH}^{-}$ ions in the hydrothermal solution. As a result of the successful formation of LDH film on the surface of PEO, the corrosion rate of the AZ31 Mg alloy substrate was significantly reduced as the $E_{\text {corr }}$ of the PEO coating increased from -1.47 to $-1.39 \mathrm{~V}$ vs. SCE while the value of $i_{c o r r}$ of PEO coating was decreased by about two orders of magnitude upon the deposition of LDH film. Recently, Petrova et al. [97] studied the effects of chelating 
agents added into the reaction system on the growth of $\mathrm{Mg}-\mathrm{Al} \mathrm{LDH}$ films on PEO-coated AZ91 Mg alloy. It was reported that the inclusion of chelating agents would assist the formation of soluble metal complexes and thus the increase of amounts of soluble $\mathrm{Al}^{3+}$ and $\mathrm{Mg}^{2+}$ cations in the $\mathrm{pH}$ range of 9.6-10.3, which is suitable for $\mathrm{LDH}$ growth. On the other hand, the LDH films formed on PEO-coated pure Mg samples helped to improve the corrosion resistance and biocompatibility of $\mathrm{Mg}$ and to enhance osteogenic activity in vivo, indicating its promising potential for orthopedic applications [98].
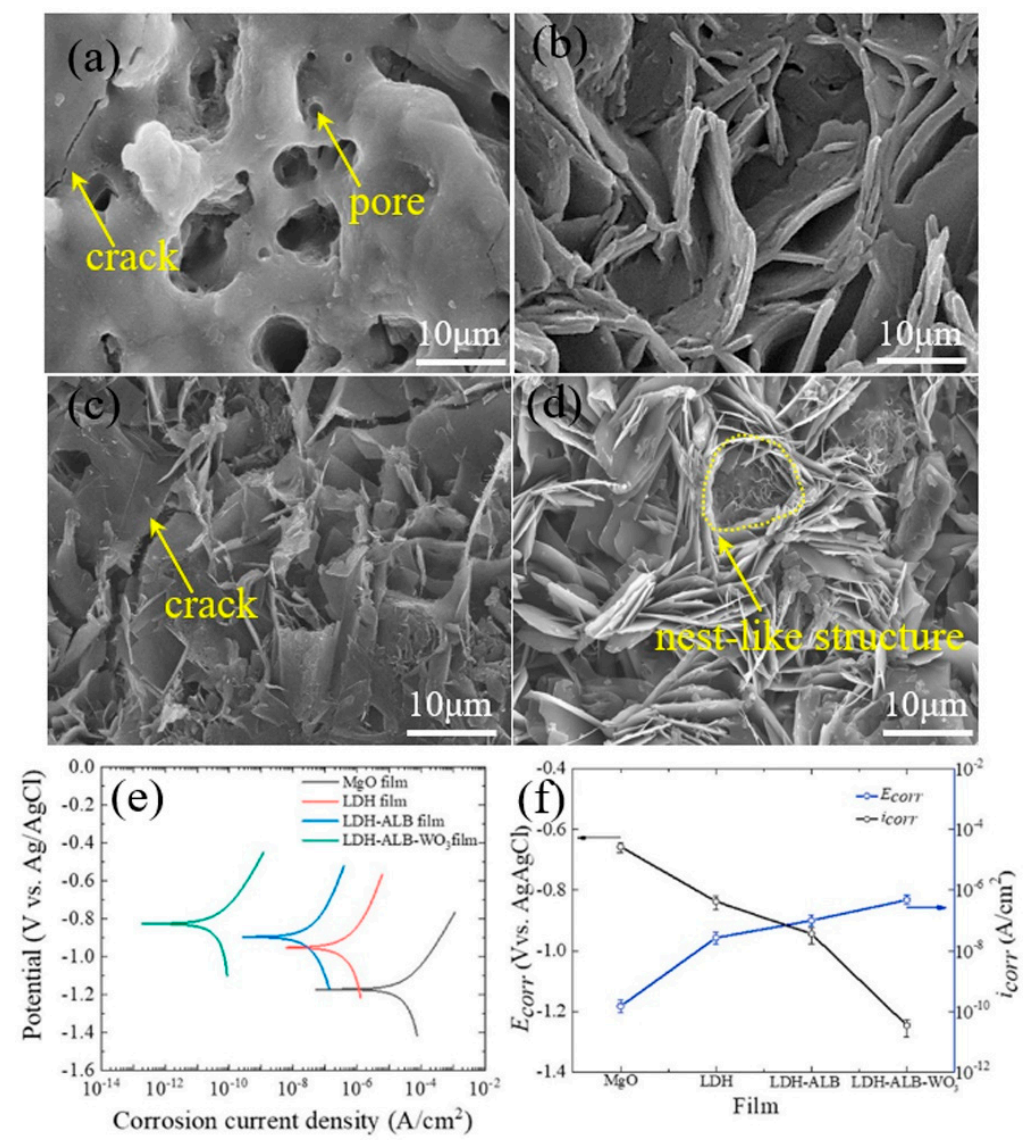

Figure 7. (a-d) SEM images showing the surface morphologies of MgO, LDH, LDH-ALB (albumin), and $\mathrm{LDH}-\mathrm{ALB}-\mathrm{WO}_{3}$ films, respectively. (e) Potentiodynamic polarization (PDP) curves of the obtained films in a $3.5 \mathrm{wt} . \% \mathrm{NaCl}$ solution. (f) The variation of $E_{\text {corr }}$ and $i_{\text {corr }}$ the obtained films in a 3.5 wt.\% NaCl solution. Reprinted with permission from ref. [94]. Copyright 2021 Elsevier.

\subsection{Performance of LDH Films in Comparison with Other Post-Treatment Methods}

As shown above, the production of LDHs film on the anodic films of Mg alloys helped to improve their corrosion resistance in corrosive media. However, a comparison between the effects of LDHs film in comparison with other surface modification methods on the corrosion performance of the anodic film of $\mathrm{Mg}$ alloys would be needed. Table 1 sums up the electrochemical parameters $\left(i_{c o r r}\right.$ and $E_{\text {corr }}$ ) obtained from PDP curves for the anodic films of Mg alloys (AZ31 and AZ91) post-treated via LDHs film and other surface modification methods. The conclusion can be drawn from Table 1 that the protective properties of the anodic films of $\mathrm{Mg}$ alloys can be improved by post-treatment methods, regardless of the type of post-treatment. However, the modification of the anodic films by LDH-based films would be more desirable and more effective than other methods due to the significant improvements in the corrosion resistance and long-term corrosion properties, feasible, and relatively eco-friendly procedures during the modification by LDH films. 
Table 1. Summary of $i_{\text {corr }}$ and $E_{\text {corr }}$ obtained from the potentiodynamic polarization tests of the anodic films of Mg alloys post-treated by different methods. The units for $i_{\text {corr }}$ and $E_{\text {corr }}$ are $\mu \mathrm{A} \cdot \mathrm{cm}^{-2}$ and $\mathrm{V}$, respectively, in the table.

\begin{tabular}{|c|c|c|c|c|c|c|c|}
\hline \multirow{2}{*}{ Substrate } & \multirow{2}{*}{$\begin{array}{l}\text { Solution/Electrode } \\
\text { for Corrosion }\end{array}$} & \multicolumn{2}{|c|}{ Anodic Film } & \multirow{2}{*}{ Post-Treatment } & \multicolumn{2}{|c|}{ Anodic Film + Post-Treatment } & \multirow{2}{*}{ Ref } \\
\hline & & $i_{\text {corr }}$ & $E_{\text {corr }}$ & & $i_{\text {corr }}$ & $E_{\text {corr }}$ & \\
\hline & & 3.89 & -0.74 & $\mathrm{LDH}-\mathrm{VO}_{3}$ film & $2.48 \times 10^{-1}$ & -0.40 & [50] \\
\hline & & 4.698 & -1.48 & Mg-Al LDH film & 0.1178 & -1.34 & [63] \\
\hline & & 2.31 & -0.46 & Ce-LDH-P film & 0.05 & -0.13 & [57] \\
\hline & & - & - & LDH-Ce-V film & 0.22 & -0.173 & [62] \\
\hline & & $4.31 \times 10^{-2}$ & -1.474 & $\begin{array}{l}\text { LDH modified by stearic } \\
\text { acid }\end{array}$ & $1.78 \times 10^{-4}$ & -1.257 & [93] \\
\hline & & 0.413 & -1.485 & $\mathrm{LDH}+\mathrm{HT}\left(0.05 \mathrm{M} \mathrm{Al}^{3+}\right)$ & $1.03 \times 10^{-3}$ & -1.350 & [91] \\
\hline & & 8.08 & -0.59 & $\mathrm{LDH}+\mathrm{HT}(12 \mathrm{~h})$ & 0.79 & -0.33 & [55] \\
\hline & & 10.33 & -0.44 & $\mathrm{LDH}+\mathrm{HT}\left(0.032 \mathrm{M} \mathrm{Al}^{3+}\right)$ & 1.040 & -0.372 & [66] \\
\hline & $\begin{array}{l}3.5 \text { wt.\% } \\
\mathrm{NaCl} / \mathrm{SCE}\end{array}$ & 0.30 & -1.58 & $\begin{array}{l}\text { high-intensity pulsed ion } \\
\text { beam }\end{array}$ & $4 \times 10^{-3}$ & -1.35 & [99] \\
\hline \multirow{14}{*}{ AZ31 Mg alloy } & & 2.58 & -1.49 & stearic acid coating & $4.1 \times 10^{-2}$ & -1.37 & [100] \\
\hline & & 2.01 & -1.42 & $\begin{array}{l}\text { polymer coating } \\
\text { (polyproblene) }\end{array}$ & $9.2 \times 10^{-4}$ & -1.47 & [101] \\
\hline & & 0.59 & -1.61 & HT & 0.29 & -1.48 & [102] \\
\hline & & 0.24 & -1.46 & $\begin{array}{l}\text { polymethyltrimethoxy- } \\
\text { silane } \\
\text { sealing }\end{array}$ & $2.86 \times 10^{-2}$ & -1.41 & [103] \\
\hline & & 0.13 & -1.30 & $\begin{array}{l}\text { Ce-based sealing + } \\
\mathrm{Al}\left(\mathrm{H}_{2} \mathrm{PO}_{4}\right)_{3} \text { sealing }\end{array}$ & 0.12 & -1.29 & [104] \\
\hline & $\begin{array}{c}\text { Hank's } \\
\text { solution/SCE }\end{array}$ & 3.72 & -1.64 & LDH & $5.69 \times 10^{-2}$ & -1.36 & [88] \\
\hline & \multirow{2}{*}{$\begin{array}{c}3.5 \text { wt. } \% \\
\mathrm{NaCl} / \mathrm{Ag} / \mathrm{AgCl}\end{array}$} & $2.26 \times 10^{-2}$ & -0.98 & $\begin{array}{c}\text { RF sputtering (Ni-Cr } \\
\text { layer) }\end{array}$ & $1.51 \times 10^{-3}$ & -0.61 & [105] \\
\hline & & 27.1 & -1.183 & $\begin{array}{l}\text { LDH modified by } \\
\text { albumin- } \mathrm{WO}_{3} \text { composite }\end{array}$ & $3.44 \times 10^{-5}$ & -0.832 & [94] \\
\hline & $\begin{array}{l}\text { phosphate bufer } \\
\text { saline/SCE }\end{array}$ & 9.45 & -1.22 & LDH-HT & 3.92 & -1.2 & [85] \\
\hline & $\begin{array}{c}5 \text { wt. } \% \\
\mathrm{NaCl} / \mathrm{Ag} / \mathrm{AgCl}\end{array}$ & 1.89 & -1.37 & electrophoretic coating & $1.93 \times 10^{-2}$ & -1.28 & [106] \\
\hline & $\begin{array}{c}5 \text { wt. } \% \\
\mathrm{NaCl} / \mathrm{Ag} / \mathrm{AgCl}\end{array}$ & 12.1 & -1.75 & $\begin{array}{l}\text { inorganic sealing }+\mathrm{CO}_{2} \\
\text { solidifying }\end{array}$ & $1.28 \times 10^{-3}$ & -1.65 & [107] \\
\hline & \multirow{3}{*}{$\mathrm{SBF} / \mathrm{SCE}$} & 2.25 & -1.56 & $\begin{array}{l}\text { self-assembly }+ \text { thiolene } \\
\text { photochemical reaction }\end{array}$ & $1.67 \times 10^{-4}$ & -1.52 & [108] \\
\hline & & 3.06 & -1.3 & $\begin{array}{c}\text { immersion in } \\
\text { EDTACa/ } \mathrm{KH}_{2} \mathrm{PO}_{4} \\
\text { solution at } 353 \mathrm{~K} \text { for } 6 \mathrm{~h}\end{array}$ & 0.42 & -0.76 & [109] \\
\hline & & 33 & -1.39 & $\mathrm{ZrO}_{2}$-sol gel sealing & 2.40 & -1.19 & [110] \\
\hline \multirow{6}{*}{ AZ91 Mg alloy } & \multirow{6}{*}{$\begin{array}{l}3.5 \text { wt. } \% \\
\mathrm{NaCl} / \mathrm{SCE}\end{array}$} & 1.27 & -1.32 & $\begin{array}{l}\text { LDH modified by } \\
\text { perfluoropolyether }\end{array}$ & $2.04 \times 10^{-4}$ & -0.85 & [86] \\
\hline & & 0.39 & -1.32 & $\mathrm{SiO}_{2}-\mathrm{ZrO}_{2}$ sol-gel coating & $1.57 \times 10^{-3}$ & -0.40 & [76] \\
\hline & & 1.60 & -1.48 & $\mathrm{TiO}_{2}$ sol-gel coating & 0.08 & -1.31 & [14] \\
\hline & & 0.40 & -1.42 & $\begin{array}{c}\text { electrodeposition of silica } \\
+8 \mathrm{HQ}\end{array}$ & $5.46 \times 10^{-3}$ & -1.38 & [111] \\
\hline & & 0.82 & -1.46 & Cyclic assembly & $3.5 \times 10^{-2}$ & -1.36 & [112] \\
\hline & & 1.5 & -1.87 & $\mathrm{La}\left(\mathrm{NO}_{3}\right)_{3}$-based sealing & 0.28 & -1.65 & [113] \\
\hline
\end{tabular}

$\mathrm{HT}=$ hydrothermal treatment, $\mathrm{SBF}=$ Simulated body fluid, $\mathrm{SCE}=$ Calomel electrode.

\section{Summary and Perspectives}

Recent studies based on LDH/anodic film composites suggested that the fabrication of LDH films on the surface of anodic films produced on the Mg alloy by either anodizing or PEO would lead to fabricating functional materials for corrosion protection applications. Several processing methods have been developed to fabricate $\mathrm{LDH} /$ anodic film composites with a uniform and compact structure, which would be the main challenge before the success of commercialization. The in situ hydrothermal method has unique advantages in fabricating LDH/anodic film composites even though this method requires using autoclave 
and high temperatures. The formation of LDH film on the anodized samples could semiseal or seal the structural defects, resulting in an improved corrosion property. However, the growth of the LDH film would be affected by several factors, such as the morphology of the anodic film, type of synthesis method, the composition of the hydrothermal solution as well as the processing parameters namely, $\mathrm{pH}$, treatment time. The self-healing and ionexchange capability of LDH film would enable it to release corrosion inhibitors and adsorb corrosive species when in contact with corrosive environments to restrain the corrosion progress. On the other hand, the LDH film can be fabricated also on the PEO coatings of $\mathrm{Mg}$ alloy; however, a balance between the dissolution rate of PEO coating and growth rate should be achieved to achieve the desired corrosion resistance. A superhydrophobic coating can be made through the surface modification of the LDH film which would further improve the protective properties of the obtained composites. LDH/PEO composite made on pure $\mathrm{Mg}$ can be used as promising implants in orthopedic applications.

Considering all the experimental results described in the present work, there is a clear potential for the use of LDH film as a final post-treatment to enable improvement in the performance of anodic films of $\mathrm{Mg}$ alloys. The key parameter for implementing the use of LDHs and derived materials is the choice of the appropriate synthesis process. Since the PEO coating has better performance than the anodized film, a better understanding of the PEO process and how the morphology and composition of the PEO coatings affect the formation of LDH film would be needed. This can be achieved by carrying out a systematic study on PEO coatings with different morphologies to have a better grasp on how to associate ideal barrier protection from the PEO coating itself and the sealing plus active corrosion protection from the "smart" LDH film. It is necessary to discover new ecofriendly corrosion inhibitors that can be intercalated into the LDH film by anion-exchange reactions since they are the main feature for active corrosion protection functionality. On the other hand, the stimulation of LDH film grown on the anodic films of Mg alloys would provide a better understanding of the functionality of these materials.

Author Contributions: M.K.: Conceptualization, writing—original draft, writing-review and editing; funding acquisition; K.R., S.H. and B.D.: writing—review and editing. All authors have read and agreed to the published version of the manuscript.

Funding: This work was supported by the National Research Foundation of Korea (NRF) grant funded by the Korea government (MSIT) (No. NRF-2019R1G1A1099335).

Informed Consent Statement: Informed consent was obtained from all subjects involved in the study. The data presented in this study are available on request from the corresponding author.

Data Availability Statement: The data presented in this study are available on request from the corresponding author.

Conflicts of Interest: The authors declare no conflict of interest.

\section{References}

1. Esmaily, M.; Svensson, J.; Fajardo, S.; Birbilis, N.; Frankel, G.; Virtanen, S.; Arrabal, R.; Thomas, S.; Johansson, L. Fundamentals and advances in magnesium alloy corrosion. Prog. Mater. Sci. 2017, 89, 92-193. [CrossRef]

2. Balaji, J.; Roh, S.H.; Edison, T.N.J.I.; Jung, H.Y.; Sethuraman, M.G. Sol-gel based hybrid silane coatings for enhanced corrosion protection of copper in aqueous sodium chloride. J. Mol. Liq. 2020, 302, 112551. [CrossRef]

3. Kuznetsov, B.; Serdechnova, M.; Tedim, J.; Starykevich, M.; Kallip, S.; Oliveira, M.P.; Hack, T.; Nixon, S.; Ferreira, M.G.S.; Zheludkevich, M.L. Sealing of tartaric sulfuric (TSA) anodized AA2024 with nanostructured LDH layers. Rsc Adv. 2016, 6, 13942-13952. [CrossRef]

4. Li, Y.; Li, S.; Zhang, Y.; Yu, M.; Liu, J. Enhanced protective Zn-Al layered double hydroxide film fabricated on anodized 2198 aluminum alloy. J. Alloy. Compd. 2015, 630, 29-36. [CrossRef]

5. Hussain, T.; Kaseem, M.; Ko, Y.G. Hard acid-hard base interactions responsible for densification of alumina layer for superior electrochemical performance. Corros. Sci. 2020, 170, 108663. [CrossRef]

6. Kaseem, M.; Choe, H.C. Triggering the hydroxyapatite deposition on the surface of PEO-coated Ti-6Al-4V alloy via the dual incorporation of $\mathrm{Zn}$ and $\mathrm{Mg}$ ions. J. Alloy. Compd. 2020, 819, 153038. [CrossRef] 
7. Kaseem, M.; Fatimah, S.; Nashrah, N.; Ko, Y.G. Recent progress in surface modification of metals coated by plasma electrolytic oxidation: Principle, structure, and performance. Prog. Mater. Sci. 2020, 100735. [CrossRef]

8. Kaseem, M.; Kamil, M.; Ko, Y. Electrochemical response of $\mathrm{MoO}_{2}-\mathrm{Al}_{2} \mathrm{O}_{3}$ oxide films via plasma electrolytic oxidation. Surf. Coatings Technol. 2017, 322, 163-173. [CrossRef]

9. Kaseem, M.; Ko, Y.G. Morphological modification and corrosion response of $\mathrm{MgO}$ and $\mathrm{Mg}_{3}(\mathrm{PO} 4)_{2}$ composite formed on magnesium alloy. Compos. Part B Eng. 2019, 176, 107225. [CrossRef]

10. Cui, L.-Y.; Zeng, R.-C.; Guan, S.-K.; Qi, W.-C.; Zhang, F.; Li, S.-Q.; Han, E.-H. Degradation mechanism of micro-arc oxidation coatings on biodegradable Mg-Ca alloys: The influence of porosity. J. Alloy. Compd. 2017, 695, 2464-2476. [CrossRef]

11. Stojadinović, S.; Vasilić, R.; Perić, M. Investigation of plasma electrolytic oxidation on valve metals by means of molecular spectroscopy-A review. RSC Adv. 2014, 4, 25759-25789. [CrossRef]

12. Narayanan, T.; Song, P.; Lee, M. Strategies to improve the corrosion resistance of microarc oxidation (MAO) coated magnesium alloys for degradable implants: Prospects and challenges. Prog. Mater. Sci. 2014, 60, 1-71. [CrossRef]

13. Kaseem, M.; Kim, M.J.; Ko, Y.G. Hydration-dehydration behavior induced densification of porous plasma electrolysis coating. J. Alloy. Compd. 2019, 798, 220-226. [CrossRef]

14. Narayanan, T.S.N.S.; Lee, M.H. A simple strategy to modify the porous structure of plasma electrolytic oxidation coatings on magnesium. RSC Adv. 2016, 6, 16100-16114. [CrossRef]

15. Li, N.; Chen, Y.; Deng, B.; Yue, J.; Qu, W.; Yang, H.; Xia, W.; Li, L. Low temperature UV assisted sol-gel preparation of ZrO 2 pore-sealing films on micro-arc oxidized magnesium alloy AZ91D and their electrochemical corrosion behaviors. J. Alloy. Compd. 2019, 792, 1036-1044. [CrossRef]

16. Kaseem, M.; Ko, Y.G. Benzoate intercalated Mg-Al-layered double hydroxides (LDHs) as efficient chloride traps for plasma electrolysis coatings. J. Alloy. Compd. 2019, 787, 772-778. [CrossRef]

17. Kaseem, M.; Ko, Y.G. A novel composite system composed of zirconia and LDHs film grown on plasma electrolysis coating: Toward a stable smart coating. Ultrason. Sonochemistry 2018, 49, 316-324. [CrossRef]

18. Scarpellini, D.; Falconi, C.; Gaudio, P.; Mattoccia, A.; Medaglia, P.G.; Orsini, A.; Pizzoferrato, R.; Richetta, M. Morphology of $\mathrm{Zn} / \mathrm{Al}$ layered double hydroxide nanosheets grown onto aluminum thin films. Microelectron. Eng. 2014, 126, 129-133. [CrossRef]

19. Bouali, A.; Serdechnova, M.; Blawert, C.; Tedim, J.; Ferreira, M.; Zheludkevich, M. Layered double hydroxides (LDHs) as functional materials for the corrosion protection of aluminum alloys: A review. Appl. Mater. Today 2020, 21, 100857. [CrossRef]

20. Chen, F.; Yu, P.; Zhang, Y. Healing effects of LDHs nanoplatelets on MAO ceramic layer of aluminum alloy. J. Alloy. Compd. 2017, 711, 342-348. [CrossRef]

21. Serdechnova, M.; Mohedano, M.; Kuznetsov, B.; Mendis, C.L.; Starykevich, M.; Karpushenkov, S.; Tedim, J.; Ferreira, M.G.S.; Blawert, C.; Zheludkevich, M.L. PEO Coatings with Active Protection Based on In-Situ Formed LDH-Nanocontainers. J. Electrochem. Soc. 2017, 164, C36-C45. [CrossRef]

22. Alibakhshi, E.; Ghasemi, E.; Mahdavian, M.; Ramezanzadeh, B. A comparative study on corrosion inhibitive effect of nitrate and phosphate intercalated Zn-Al- layered double hydroxides (LDHs) nanocontainers incorporated into a hybrid silane layer and their effect on cathodic delamination of epoxy topcoat. Corros. Sci. 2017, 115, 159-174. [CrossRef]

23. Sun, Z.; Gu, L.; Zheng, J.; Zhang, J.; Wang, L.; Xu, F.; Lin, C. A controlled release strategy of antifouling agent in coating based on intercalated layered double hydroxides. Mater. Lett. 2016, 172, 105-108. [CrossRef]

24. Lin, J.K.; Uan, J.Y. Formation of $\mathrm{Mg}$, Al-hydrotalcite conversion coating on $\mathrm{Mg}$ alloy in aqueous $\mathrm{HCO}_{3}{ }^{-} / \mathrm{CO}_{3}{ }^{2-}$ and corresponding protection against corrosion by the coating. Corros. Sci. 2009, 51, 1181-1188. [CrossRef]

25. Yu, B.-L.; Lin, J.-K.; Uan, J.-Y. Applications of carbonic acid solution for developing conversion coatings on Mg alloy. Trans. Nonferrous Met. Soc. China 2010, 20, 1331-1339. [CrossRef]

26. Chen, J.; Song, Y.; Shan, D.; Han, E.-H. In Situ Growth Process of Mg-Al Hydrotalcite Conversion Film on AZ31 Mg Alloy. J. Mater. Sci. Technol. 2015, 31, 384-390. [CrossRef]

27. Wu, H.; Zhang, L.; Zhang, Y.; Long, S.; Jie, X. Corrosion behavior of Mg-Al LDH film in-situ assembled with graphene on Mg alloy pre-sprayed Al layer. J. Alloys. Compd. 2020, 834, 155107. [CrossRef]

28. Wang, L.; Zhang, K.; Sun, W.; Wu, T.; He, H.; Liu, G. Hydrothermal synthesis of corrosion resistant hydrotalcite conversion coating on AZ91D alloy. Mater. Lett. 2013, 106, 111-114. [CrossRef]

29. Peng, F.; Li, H.; Wang, D.; Tian, P.; Tian, Y.; Yuan, G.; Xu, D.; Liu, X. Enhanced Corrosion Resistance and Biocompatibility of Magnesium Alloy by Mg-Al-Layered Double Hydroxide. ACS Appl. Mater. Interfaces 2016, 8, 35033-35044. [CrossRef]

30. Chen, J.; Song, Y.; Shan, D.; Han, E.-H. Influence of alloying elements and microstructure on the formation of hydrotalcite film on Mg alloys. Corros. Sci. 2015, 93, 90-99. [CrossRef]

31. Lin, J.K.; Hsia, C.L.; Uan, J.Y. Characterization of Mg, Alhydrotalcite conversion film on $\mathrm{Mg}$ alloy and $\mathrm{Cl}^{-}$and $\mathrm{CO}_{3}{ }^{2-}$ anionexchangeability of the film in a corrosive environment. Scr. Mater. 2007, 56, 927-930. [CrossRef]

32. Zeng, R.-C.; Li, X.-T.; Liu, Z.-G.; Zhang, F.; Li, S.-Q.; Cui, H.-Z. Corrosion resistance of Zn-Al layered double hydroxide/poly (lactic acid) composite coating on magnesium alloy AZ31. Front. Mater. Sci. 2015, 9, 355-365. [CrossRef]

33. Zhang, F.; Zhang, C.; Zeng, R.; Song, L.; Guo, L.; Huang, X. Corrosion Resistance of the Superhydrophobic Mg(OH) $2 / \mathrm{Mg}-\mathrm{Al}$ Layered Double Hydroxide Coatings on Magnesium Alloys. Metals 2016, 6, 85. [CrossRef] 
34. Zeng, R.-C.; Liu, L.-J.; Pang, T.-T.; Zhang, F.; Zhang, W.-W.; Li, S.-Q.; Cui, H.-Z.; Han, E.-H. Corrosion Resistance of Silane-Modified Hydroxide Zinc Carbonate Film on AZ31 Magnesium Alloy. Acta Met. Sin. 2015, 28, 373-380. [CrossRef]

35. Ba, Z.; Dong, Q.; Zhang, X.; Qiang, X.; Cai, Z.; Luo, X. Cerium-based modification treatment of Mg-Al hydrotalcite film on AZ91D $\mathrm{Mg}$ alloy assisted with alternating electric field. J. Alloy. Compd. 2017, 695, 106-113. [CrossRef]

36. Lai, F.; Miao, Y.-E.; Zuo, L.; Lu, H.; Huang, Y.; Liu, T. Biomass-Derived Nitrogen-Doped Carbon Nanofiber Network: A Facile Template for Decoration of Ultrathin Nickel-Cobalt Layered Double Hydroxide Nanosheets as High-Performance Asymmetric Supercapacitor Electrode. Small 2016, 12, 3235-3244. [CrossRef] [PubMed]

37. Mallakpour, S.; Dinari, M.; Behranvand, V. Ultrasonic-assisted synthesis and characterization of layered double hydroxides intercalated with bioactive N,N'-(pyromellitoyl)-bis-l- $\alpha$-amino acids. RSC Adv. 2013, 3, 23303-23308. [CrossRef]

38. Basu, D.; Das, A.; Stöckelhuber, K.W.; Wagenknecht, U.; Heinrich, G. Advances in layered double hydroxide (LDH)-based elastomer composites. Prog. Polym. Sci. 2014, 39, 594-626. [CrossRef]

39. Iqbal, M.A.; Sun, L.; la Chance, A.M.; Ding, H.; Fedel, M. In situ growth of a CaAl-NO $-\mathrm{NO}_{3}$-layered double hydroxide film directly on an aluminum alloy for corrosion resistance. Dalton Trans. 2020, 49, 3956-3964. [CrossRef] [PubMed]

40. Ishizaki, T.; Kamiyama, N.; Watanabe, K.; Serizawa, A. Corrosion resistance of $\mathrm{Mg}(\mathrm{OH})_{2} / \mathrm{Mg}-\mathrm{Al}$ layered double hydroxide composite film formed directly on combustion-resistant magnesium alloy AMCa602 by steam coating. Corros. Sci. 2015, 92, 76-84. [CrossRef]

41. Kamiyama, N.; Panomsuwan, G.; Yamamoto, E.; Sudare, T.; Saito, N.; Ishizaki, T. Effect of treatment time in the $\mathrm{Mg}(\mathrm{OH})_{2} / \mathrm{Mg}-\mathrm{Al}$ LDH composite film formed on Mg alloy AZ31 by steam coating on the corrosion resistance. Surf. Coat. Technol. 2016, 286, 172-177. [CrossRef]

42. Wu, F.; Liang, J.; Peng, Z.; Liu, B. Electrochemical deposition and characterization of Zn-Al layered double hydroxides (LDHs) films on magnesium alloy. Appl. Surf. Sci. 2014, 313, 834-840. [CrossRef]

43. Tabish, M.; Yasin, G.; Anjum, M.J.; Malik, M.U.; Zhao, J.; Yang, Q.; Manzoor, S.; Murtaza, H.; Khan, W.Q. Reviewing the current status of layered double hydroxide-based smart nanocontainers for corrosion inhibiting applications. J. Mater. Res. Technol. 2021, 10, 390-421. [CrossRef]

44. Guo, L.; Wu, W.; Zhou, Y.; Zhang, F.; Zeng, R.; Zeng, J. Layered double hydroxide coatings on magnesium alloys: A review. J. Mater. Sci. Technol. 2018, 34, 1455-1466. [CrossRef]

45. Chen, J.; Song, Y.; Shan, D.; Han, E.-H. Study of the in situ growth mechanism of Mg-Al hydrotalcite conversion film on AZ31 magnesium alloy. Corros. Sci. 2012, 63, 148-158. [CrossRef]

46. Chen, J.; Song, Y.; Shan, D.; Han, E.-H. In situ growth of Mg-Al hydrotalcite conversion film on AZ31 magnesium alloy. Corros. Sci. 2011, 53, 3281-3288. [CrossRef]

47. Shulha, T.N.; Serdechnova, M.; Lamaka, S.V.; Wieland, D.C.F.; Lapko, K.N.; Zheludkevich, M.L. Chelating agent-assisted in situ LDH growth on the surface of magnesium alloy. Sci. Rep. 2018, 8, 16409. [CrossRef] [PubMed]

48. Zhao, Y.; Waterhouse, G.I.N.; Chen, G.; Xiong, X.; Wu, L.-Z.; Tung, C.-H.; Zhang, T. Two-dimensional-related catalytic materials for solar-driven conversion of $\mathrm{CO}_{x}$ into valuable chemical feedstocks. Chem. Soc. Rev. 2019, 48, 1972-2010. [CrossRef]

49. Nakayama, H.; Hayashi, A. Mixing Acid Salts and Layered Double Hydroxides in Nanoscale under Solid Condition. Pharmaceutics 2014, 6, 436-446. [CrossRef]

50. Zhang, G.; Wu, L.; Tang, A.; Zhang, S.; Yuan, B.; Zheng, Z.; Pan, F. A novel approach to fabricate protective layered double hydroxide films on the surface of anodized Mg-Al alloy. Adv. Mater. Interfaces 2017, 4, 1700163. [CrossRef]

51. Zeng, R.-C.; Liu, Z.-G.; Zhang, F.; Li, S.-Q.; Cui, H.-Z.; Han, E.-H. Corrosion of molybdate intercalated hydrotalcite coating on AZ31 Mg alloy. J. Mater. Chem. A 2014, 2, 13049-13057. [CrossRef]

52. Eliseev, A.; Lukashin, A.V.; Vertegel, A.A.; Tarasov, V.P.; Tret'yakov, Y.D. A Study of Crystallization of Mg-Al Double Hydroxides. Dokl. Chem. 2002, 387, 339-343. [CrossRef]

53. Seron, A.; Delorme, F. Synthesis of layered double hydroxides (LDHs) with varying pH: A valuable contribution to the study of $\mathrm{Mg} / \mathrm{Al} \mathrm{LDH}$ formation mechanism. J. Phys. Chem. Solids 2008, 69, 1088-1090. [CrossRef]

54. Yang, Y.; Zhao, X.; Zhu, Y.; Zhang, F. Transformation Mechanism of Magnesium and Aluminum Precursor Solution into Crystallites of Layered Double Hydroxide. Chem. Mater. 2011, 24, 81-87. [CrossRef]

55. Zhang, G.; Wu, L.; Tang, A.; Chen, X.B.; Ma, Y.; Long, Y.; Penga, P.; Dinga, X.; Pan, H.; Pan, F. Growth behavior of MgAl-layered double hydroxide films by conversion of anodic films on magnesium alloy AZ31 and their corrosion protection. Appl. Surf. Sci. 2018, 456, 419-429. [CrossRef]

56. Lü, Z.; Zhang, F.; Lei, X.; Yang, L.; Xu, S.; Duan, X. In situ growth of layered double hydroxide films on anodic aluminum oxide/aluminum and its catalytic feature in aldol condensation of acetone. Chem. Eng. Sci. 2008, 63, 4055-4062. [CrossRef]

57. Zhang, G.; Wu, L.; Tang, A.; Ma, Y.; Song, G.-L.; Zheng, D.; Jiang, B.; Atrens, A.; Pan, F. Active corrosion protection by a smart coating based on a MgAl-layered double hydroxide on a cerium-modified plasma electrolytic oxidation coating on $\mathrm{Mg}$ alloy AZ31. Corros. Sci. 2018, 139, 370-382. [CrossRef]

58. Zhang, G.; Wu, L.; Tang, A.; Pan, H.; Ma, Y.; Zhan, Q.; Tan, Q.; Pan, F.; Atrens, A. Effect of Micro-Arc Oxidation Coatings Formed at Different Voltages on the In Situ Growth of Layered Double Hydroxides and Their Corrosion Protection. J. Electrochem. Soc. 2018, 165, C317-C327. [CrossRef]

59. Wu, L.; Zhang, G.; Tang, A.; Liu, Y.; Atrens, A.; Pan, F. Communication-Fabrication of Protective Layered Double Hydroxide Films by Conversion of Anodic Films on Magnesium Alloy. J. Electrochem. Soc. 2017, 164, C339-C341. [CrossRef] 
60. Wu, L.; Wu, J.; Zhang, Z.; Zhang, C.; Zhang, Y.; Tang, A.; Li, L.; Zhang, G.; Zheng, Z.; Atrens, A.; et al. Corrosion resistance of fatty acid and fluoroalkylsilane-modified hydrophobic Mg-Al LDH films on anodized magnesium alloy. Appl. Surf. Sci. 2019, 487, 569-580. [CrossRef]

61. Zhang, G.; Tang, A.; Wu, L.; Zhang, Z.; Liao, H.; Long, Y.; Li, L.; Atrens, A.; Pan, F. In-situ grown super- or hydrophobic Mg-Al layered double hydroxides films on the anodized magnesium alloy to improve corrosion properties. Surf. Coatings Technol. 2019, 366, 238-247. [CrossRef]

62. Bouali, A.; André, N.; Campos, M.S.; Serdechnova, M.; dos Santos, J.; Amancio-Filho, S.; Zheludkevich, M. Influence of LDH conversion coatings on the adhesion and corrosion protection of friction spot-joined AA2024-T3/CF-PPS. J. Mater. Sci. Technol. 2021, 67, 197-210. [CrossRef]

63. Wu, L.; Yang, D.; Zhang, G.; Zhang, Z.; Zhang, S.; Tang, A.; Pan, F. Fabrication and characterization of Mg-M layered double hydroxide films on anodized magnesium alloy AZ31. Appl. Surf. Sci. 2018, 431, 177-186. [CrossRef]

64. Wu, L.; Pan, F.; Liu, Y.; Zhang, G.; Tang, A.; Atrens, A. Influence of pH on the growth behavior of Mg-Al LDH films. Surf. Eng. 2017, 34, 674-681. [CrossRef]

65. Wu, L.; Zheng, Z.; Pan, F.; Tang, A.; Zhang, G.; Liu, L. Influence of reaction temperature on the controlled growth of Mg-Al LDH film. Int. J. Electrochem. Sci. 2017, 12, 6352-6364. [CrossRef]

66. Wu, L.; Ding, X.-X.; Zhao, X.-F.; Liu, Y.-H.; Hao, X.-L.; Tang, A.-T.; Zhang, G.; Pan, F.-S. Morphology, structure and corrosion resistance of $\mathrm{Mg}-\mathrm{Al} \mathrm{LDH}$ films fabricated in different $\mathrm{Al}^{3+}$ concentration solutions. Rare Met. 2019, 1-8. [CrossRef]

67. Zhang, G.; Wu, L.; Tang, A.; Weng, B.; Atrens, A.; Ma, S.; Liu, L.; Pan, F. Sealing of anodized magnesium alloy AZ31 with MgAl layered double hydroxides layers. RSC Adv. 2018, 8, 2248-2259. [CrossRef]

68. Kamil, M.; Kaseem, M.; Lee, Y.; Ko, Y. Microstructural characteristics of oxide layer formed by plasma electrolytic oxidation: Nanocrystalline and amorphous structures. J. Alloy. Compd. 2017, 707, 167-171. [CrossRef]

69. Kaseem, M.; Kwon, J.H.; Ko, Y.G. Modification of a porous oxide layer formed on an Al-Zn-Mg alloy via plasma electrolytic oxidation and post treatment using oxalate ions. RSC Adv. 2016, 6, 107109-107113. [CrossRef]

70. Malayoglu, U.; Tekin, K.C.; Shrestha, S. Influence of post-treatment on the corrosion resistance of PEO coated AM50B and AM60B Mg alloys. Surf. Coatings Technol. 2010, 205, 1793-1798. [CrossRef]

71. Kaseem, M.; Hussain, T.; Baek, S.H.; Ko, Y.G. Formation of stable coral reef-like structures via self-assembly of functionalized polyvinyl alcohol for superior corrosion performance of AZ31 Mg alloy. Mater. Des. 2020, 193, 108823. [CrossRef]

72. Kaseem, M.; Ko, Y.G. Formation of flower-like structures for optimizing the corrosion resistance of Mg alloy. Mater. Lett. 2018, 221, 196-200. [CrossRef]

73. Kaseem, M.; Yang, H.W.; Ko, Y.G. Toward a nearly defect-free coating via high-energy plasma sparks. Sci. Rep. 2017, 7, 2378. [CrossRef]

74. Kaseem, M.; Ko, Y.G. On the compactness of the oxide layer induced by utilizing a porosification agent. Appl. Surf. Sci. 2019, 473, 715-725. [CrossRef]

75. Alabbasi, A.; Mehjabeen, A.; Kannan, M.B.; Ye, Q.; Blawert, C. Biodegradable polymer for sealing porous PEO layer on pure magnesium: An in vitro degradation study. Appl. Surf. Sci. 2014, 301, 463-467. [CrossRef]

76. Shang, W.; Chen, B.; Shi, X.; Chen, Y.; Xiao, X. Electrochemical corrosion behavior of composite MAO/sol-gel coatings on magnesium alloy AZ91D using combined micro-arc oxidation and sol-gel technique. J. Alloy. Compd. 2009, 474, 541-545. [CrossRef]

77. Li, Z.; Jing, X.; Yuan, Y.; Zhang, M. Composite coatings on a Mg-Li alloy prepared by combined plasma electrolytic oxidation and sol-gel techniques. Corros. Sci. 2012, 63, 358-366. [CrossRef]

78. Zhang, Y.; Yu, P.; Wang, J.; Li, Y.; Chen, F.; Wei, K.; Zuo, Y. LDHs/graphene film on aluminum alloys for active protection. Appl. Surf. Sci. 2018, 433, 927-933. [CrossRef]

79. Mohedano, M.; Serdechnova, M.; Starykevich, M.; Karpushenkov, S.; Bouali, A.; Ferreira, M.; Zheludkevich, M. Active protective PEO coatings on AA2024: Role of voltage on in-situ LDH growth. Mater. Des. 2017, 120, 36-46. [CrossRef]

80. Bouali, A.C.; Straumal, E.A.; Serdechnova, M.; Wieland, D.C.F.; Starykevich, M.; Blawert, C.; Hammel, J.U.; Lermontov, S.A.; Ferreira, M.G.S.; Zheludkevich, M.L. Layered double hydroxide based active corrosion protective sealing of plasma electrolytic oxida-tion/sol-gel composite coating on AA2024. Appl. Surf. Sci. 2019, 494, 829-840. [CrossRef]

81. Liu, L.; Wu, L.; Chen, X.; Sun, D.; Chen, Y.; Zhang, G.; Ding, X.; Pan, F. Enhanced protective coatings on Ti-10V-2Fe-3Al alloy through anodizing and post-sealing with layered double hydroxides. J. Mater. Sci. Technol. 2020, 37, 104-113. [CrossRef]

82. Del Olmo, R.; Mohedano, M.; Mingo, B.; Arrabal, R.; Matykina, E. LDH Post-Treatment of Flash PEO Coatings. Coatings 2019, 9 , 354. [CrossRef]

83. Zhang, Y. Investigating the Growth Behavior of LDH Layers on MAO- coated Aluminum Alloy: Influence of Microstructure and Surface Element. Int. J. Electrochem. Sci. 2018, 13, 610-620. [CrossRef]

84. Chen, J.; Lin, W.; Liang, S.; Zou, L.; Wang, C.; Wang, B.; Yan, M.; Cui, X. Effect of alloy cations on corrosion resistance of LDH/MAO coating on magnesium alloy. Appl. Surf. Sci. 2019, 463, 535-544. [CrossRef]

85. Peng, F.; Wang, D.; Tian, Y.; Cao, H.; Qiao, Y.; Liu, X. Sealing the Pores of PEO Coating with Mg-Al Layered Double Hydroxide: Enhanced Corrosion Resistance, Cytocompatibility and Drug Delivery Ability. Sci. Rep. 2017, 7, 8167. [CrossRef] 
86. Jiang, D.; Xia, X.; Hou, J.; Cai, G.; Zhang, X.; Dong, Z. A novel coating system with self-reparable slippery surface and active corrosion inhibition for reliable protection of Mg alloy. Chem. Eng. J. 2019, 373, 285-297. [CrossRef]

87. Chen, J.; Liang, S.; Fu, D.; Fan, W.; Lin, W.; Ren, W.; Zou, L.; Cui, X. Design and in situ prepare a novel composite coating on Mg alloy for active anti-corrosion protection. J. Alloy. Compd. 2020, 831, 154580. [CrossRef]

88. Li, C.-Y.; Fan, X.-L.; Zeng, R.-C.; Cui, L.-Y.; Li, S.-Q.; Zhang, F.; He, Q.-K.; Kannan, M.B.; Jiang, H.-W.; Chen, D.-C.; et al. Corrosion resistance of in-situ growth of nano-sized $\mathrm{Mg}(\mathrm{OH})_{2}$ on micro-arc oxidized magnesium alloy AZ31-Influence of EDTA. J. Mater. Sci. Technol. 2019, 35, 1088-1098. [CrossRef]

89. Li, C.-Y.; Gao, L.; Fan, X.-L.; Zeng, R.-C.; Chen, D.-C.; Zhi, K.-Q. In vitro degradation and cytocompatibility of a low temperature in-situ grown self-healing Mg-Al LDH coating on MAO-coated magnesium alloy AZ31. Bioact. Mater. 2020, 5, 364-376. [CrossRef]

90. Zhang, J.-M.; Wang, K.; Duan, X.; Zhang, Y.; Cai, H.; Wang, Z.-H. Effect of Hydrothermal Treatment Time on Microstructure and Corrosion Behavior of Micro-arc Oxidation/Layered Double Hydroxide Composite Coatings on LA103Z Mg-Li Alloy in 3.5 wt.\% $\mathrm{NaCl}$ Solution. J. Mater. Eng. Perform. 2020, 29, 4032-4039. [CrossRef]

91. Wang, Z.; Zhang, J.; Bai, L.; Zhang, G. Effects of Al 3+ concentration in hydrothermal solution on the microstructural and corrosion resistance properties of fabricated MgO ceramic layer on AZ31 magnesium alloy. Mater. Corros. 2020, 1-13. [CrossRef]

92. Peng, F.; Wang, D.; Zhang, D.; Yan, B.; Cao, H.; Qiao, Y.; Liu, X. PEO/Mg-Zn-Al LDH composite coating on Mg alloy as a $\mathrm{Zn} / \mathrm{Mg}$ ion-release platform with multifunctions: Enhanced corrosion resistance, osteogenic, and antibacterial activities. ACS Biomater. Sci. Eng. 2018, 4, 4112-4121. [CrossRef]

93. Wang, Z.-H.; Zhang, J.-M.; Li, Y.; Bai, L.-J.; Zhang, G.-J. Enhanced corrosion resistance of micro-arc oxidation coated magnesium alloy by superhydrophobic Mg-Al layered double hydroxide coating. Trans. Nonferrous Met. Soc. China 2019, 29, $2066-2077$. [CrossRef]

94. Kaseem, M.; Ko, Y.G. A novel hybrid composite composed of albumin, $\mathrm{WO}_{3}$, and $\mathrm{LDHs}$ film for smart corrosion protection of $\mathrm{Mg}$ alloy. Compos. Part B Eng. 2021, 204, 108490. [CrossRef]

95. Zhang, J.; Zhang, Y.; Wang, K.; Duan, X.; Hui, C.; Wang, Z.-H. The Influence of Holding Time on Morphologies and Electrochemical Properties of MAO/LDH Composite Film on LA103Z Mg-Li Alloy. Trans. Indian Ceram. Soc. 2020, 79, 166-171. [CrossRef]

96. Wang, Z.H.; Zhang, J.M.; Li, Y.; Bai, L.J.; Zhang, G.J. Corrosion Resistance Enhancement of Micro-Arc Oxidation Ceramic Layer by Mg-Al-Co Layered Double Hydroxide Coating. Trans. Indian Ceram. Soc. 2020, 79, 59-66. [CrossRef]

97. Petrova, E.; Serdechnova, M.; Shulha, T.; Lamaka, S.V.; Wieland, D.C.F.; Karlova, P.; Blawert, C.; Starykevich, M.; Zheludkevich, M.L. Use of synergistic mixture of chelating agents for in situ LDH growth on the surface of PEO-treated AZ91. Sci. Rep. 2020, 10, 8645. [CrossRef]

98. Wang, J.; Peng, F.; Wu, X.; Wang, D.; Zheng, A.; Cao, L.; Yu, C.; Liu, X.; Jiang, X. Biocompatibility and bone regeneration of $\mathrm{PEO} / \mathrm{Mg}-\mathrm{Al} \mathrm{LDH}$-coated pure Mg: An in vitro and in vivo study. Sci. China Mater. 2021, 64, 460-473. [CrossRef]

99. Han, X.; Zhu, X.; Lei, M. Electrochemical properties of microarc oxidation films on a magnesium alloy modified by high-intensity pulsed ion beam. Surf. Coatings Technol. 2011, 206, 874-878. [CrossRef]

100. Cui, X.-J.; Lin, X.-Z.; Liu, C.-H.; Yang, R.-S.; Zheng, X.-W.; Gong, M. Fabrication and corrosion resistance of a hydrophobic micro-arc oxidation coating on AZ31 Mg alloy. Corros. Sci. 2015, 90, 402-412. [CrossRef]

101. Chen, M.-A.; Xiao, C.; Li, J.-M. Improvement of corrosion performance of MAO coated AZ31 magnesium alloy by polypropylene post-treatment. Trans. IMF 2013, 91, 80-87. [CrossRef]

102. Dey, A.; Rani, R.U.; Thota, H.K.; Sharma, A.K.; Bandyopadhyay, P.; Mukhopadhyay, A.K. Microstructural, corrosion and nanomechanical behaviour of ceramic coatings developed on magnesium AZ31 alloy by micro arc oxidation. Ceram. Int. 2013, 39, 3313-3320. [CrossRef]

103. Cui, L.-Y.; Gao, S.-D.; Li, P.-P.; Zeng, R.-C.; Zhang, F.; Li, S.-Q.; Han, E.-H. Corrosion resistance of a self-healing micro-arc oxidation/polymethyltrimethoxysilane composite coating on magnesium alloy AZ31. Corros. Sci. 2017, 118, 84-95. [CrossRef]

104. Tu, W.; Cheng, Y.; Zhan, T.; Han, J.; Cheng, Y. Influence of sodium tungstate and sealing treatment on corrosion resistance of coatings formed on AZ31 magnesium alloy by plasma electrolytic oxidation. Int. J. Electrochem. Sci. 2017, 12, 10863-10881. [CrossRef]

105. Fatimah, S.; Khoerunnisa, F.; Kwon, J.; Kim, Y.; Ko, Y. Inorganic-metallic bilayer on Mg alloy via wet and dry plasma treatments. Surf. Coatings Technol. 2019, 360, 56-63. [CrossRef]

106. Wang, C.; Jiang, B.; Liu, M.; Ge, Y. Corrosion characterization of micro-arc oxidization composite electrophoretic coating on AZ31B magnesium alloy. J. Alloy. Compd. 2015, 621, 53-61. [CrossRef]

107. Yang, W.; Wang, A.-Y.; Jiang, B.-L. Corrosion resistance of composite coating on magnesium alloy using combined microarc oxidation and inorganic sealing. Trans. Nonferrous Met. Soc. China 2012, 22, s760-s763. [CrossRef]

108. Chen, Y.; Yan, G.; Wang, X.; Qian, H.; Yi, J.; Huang, L.; Liu, P. Bio-functionalization of micro-arc oxidized magnesium alloys via thiol-ene photochemistry. Surf. Coatings Technol. 2015, 269, 191-199. [CrossRef]

109. Tang, H.; Yu, D.; Luo, Y.; Wang, F. Preparation and characterization of HA microflowers coating on AZ31 magnesium alloy by micro-arc oxidation and a solution treatment. Appl. Surf. Sci. 2013, 264, 816-822. [CrossRef]

110. Chu, C.; Han, X.; Xue, F.; Bai, J.; Chu, P. Effects of sealing treatment on corrosion resistance and degradation behavior of micro-arc oxidized magnesium alloy wires. Appl. Surf. Sci. 2013, 271, 271-275. [CrossRef] 
111. Jiang, D.; Xia, X.; Hou, J.; Zhang, X.; Dong, Z. Enhanced Corrosion Barrier of Microarc-Oxidized Mg Alloy by Self-Healing Superhydrophobic Silica Coating. Ind Eng Chem Res 2009, 58, 165-178. [CrossRef]

112. Jiang, D.; Zhou, H.; Wan, S.; Cai, G.Y.; Dong, Z.H. Fabrication of superhydrophobic coating on magnesium alloy with improved corrosion resistance by combining micro-arc oxidation and cyclic assembly. Surf. Coat. Technol. 2018, 339, 155-166. [CrossRef]

113. Pezzato, L.; Brunelli, K.; Babbolin, R.; Dolcet, P.; Dabal, M. Sealing of PEO coated AZ91 magnesium alloy using La-Based solutions. Int. J. Corros. 2017, 2017, 5305218. [CrossRef] 